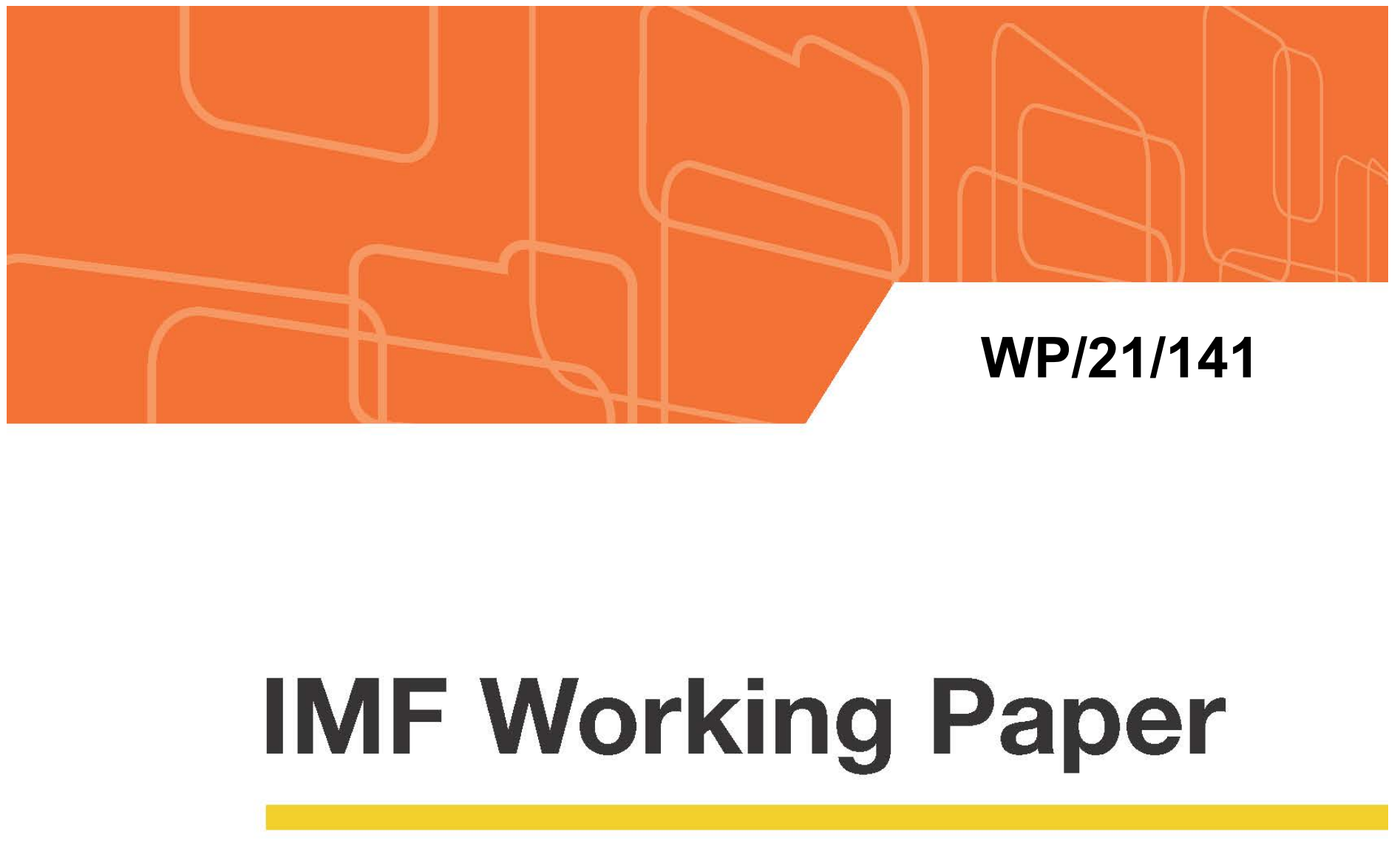

\title{
Inclusivity in the Labor Market
}

by Asmaa El-Ganainy, Ekkehard Ernst, Rossana

Merola, Richard Rogerson, and Martin Schindler

IMF Working Papers describe research in progress by the author(s) and are published to elicit comments and to encourage debate. The views expressed in IMF Working Papers are those of the author(s) and do not necessarily represent the views of the IMF, its Executive Board, or IMF management. 


\title{
IMF Working Paper
}

Institute for Capacity Development

\section{Inclusivity in the Labor Market}

\begin{abstract}
Prepared by Asmaa El-Ganainy (IMF), Ekkehard Ernst (ILO), Rossana Merola (ILO), Richard Rogerson (Princeton), Martin Schindler (IMF)
\end{abstract}

\section{Authorized for distribution by Valerie Cerra ${ }^{1}$}

May 2021

IMF Working Papers describe research in progress by the author(s) and are published to elicit comments and to encourage debate. The views expressed in IMF Working Papers are those of the author(s) and do not necessarily represent the views of the IMF, its Executive Board, or IMF management.

\begin{abstract}
Labor earnings are the dominant income source for most individuals. Thus, an inclusive labor market is key for ensuring inclusive growth. In this paper we propose four principles that an inclusive labor market will embody: access, fairness, protection and voice. While measuring inclusivity presents challenges, we discuss how data can be used to shed light on the extent of inclusivity and document cross-country trends and stylized facts. We also discuss the role of policy in achieving an inclusive labor market, focusing on the need to rebalance growth; improve risk sharing; and fight discrimination. Several messages emerge. First, some policies entail a trade-off between the different dimensions of inclusivity. Second, it is important to view policies as a bundle, taking into account substitution and complementarities. Third, some policies are win-win, in the sense that they both increase inclusivity and improve overall efficiency.
\end{abstract}

JEL Classification: E0; E2; J0; J3; J5; J7

Keywords: Inclusive Growth; Inclusive Labor Markets; Informal Economy; Labor Market Policies; Discrimination; Monopsony

Authors‘ E-Mail Addresses: aelganainy@imf.org; ernste@ilo.org; merola@ilo.org; rdr@princeton.edu; mschindler@imf.org

\footnotetext{
${ }^{1}$ We thank Jaime Sarmiento Monroy for the excellent research assistance. We also thank Valerie Cerra, Moya Chin, Romain Duval, Barry Eichengreen, Prakash Loungani, as well as participants in the Inclusive Growth book seminar series organized by the IMF Institute for Capacity Development for their comments. This is an extended draft of a chapter that has been accepted for publication by Oxford University Press in the forthcoming book titled: "How to Achieve Inclusive Growth", edited by V. Cerra, B. Eichengreen, A. ElGanainy, and M. Schindler due for publication in 2021.
} 


\section{Contents}

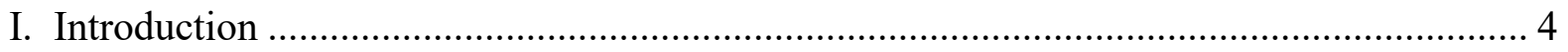

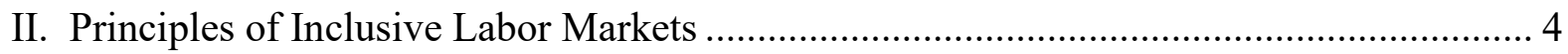

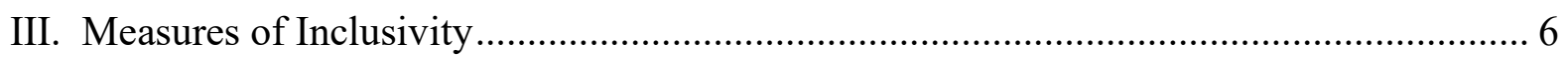

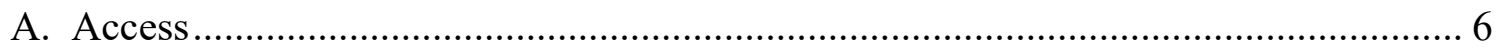

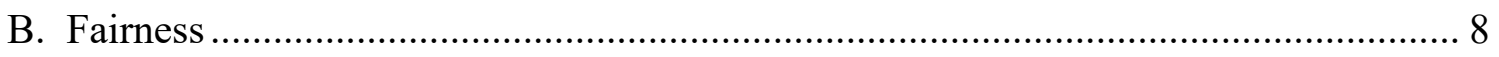

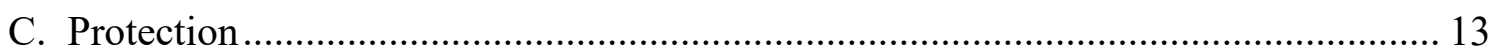

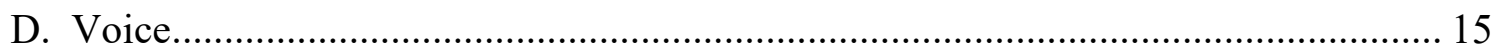

E. Informality as a Cross-Cutting Issue................................................................. 18

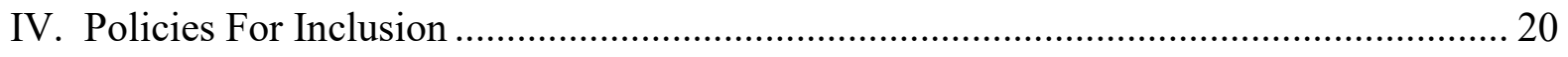

A. Rebalancing Market Power ……….............................................................. 22

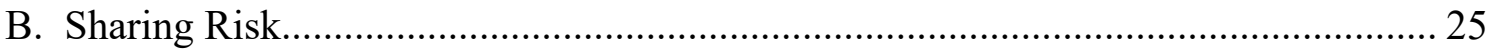

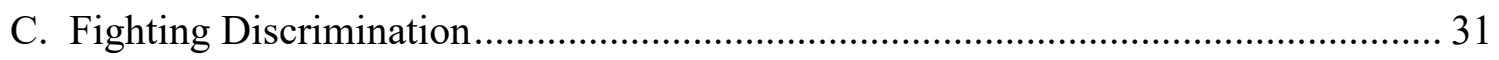

D. Addresing Labor Market Segmentation ………………...................................... 33

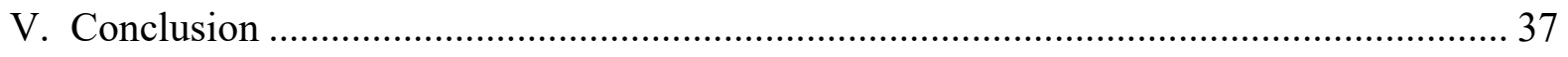

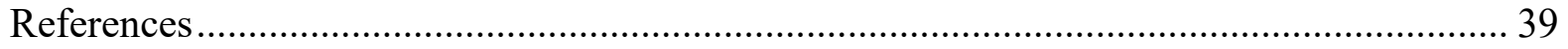

\section{Figures}

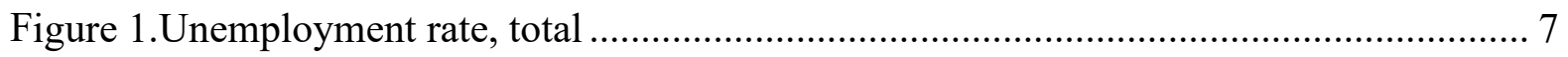

Figure 2. Employment to population ratio, total..........................................................

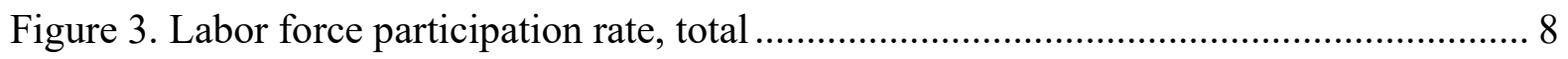

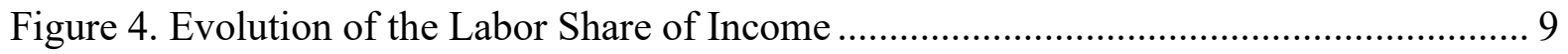

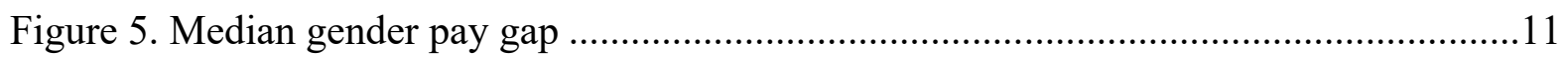

Figure 6. Median black male wage for every $\$ 1$ earned by white men ...................................11

Figure 7. Share of countries with an unemployment insurance system................................ 14

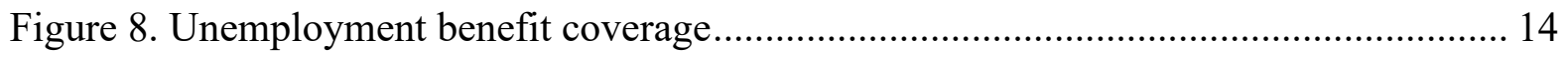

Figure 9. Procedural requirements for individual dismissals of regular workers ....................14

Figure 10. Share of countries with minimum wage legislation by country groups ................ 15

Figure 11. Proportion of population covered by social protection floors .............................. 15

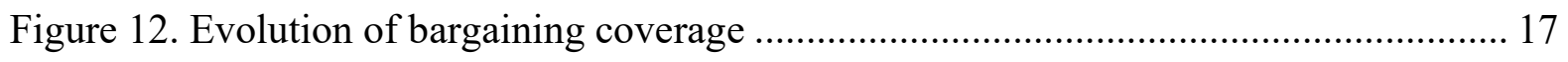

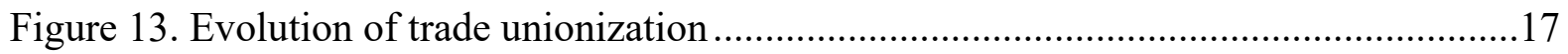

Figure 14. Share of informal employment outside agriculture ........................................... 19

Figure 15. Output Losses from Gender Discrimination....................................................... 31 


\section{INTRODUCTION}

For the vast majority of individuals, payment from selling their labor services in the labor market is the single most important source of income and hence the dominant determinant of their material standard of living. For this reason, the labor market has a key role to play in achieving inclusive growth.

Labor market inclusivity is inherently a multi-dimensional notion. Labor market opportunities encompass not only pay, but also the type of work; the working conditions, such as safety and ability to work flexible hours; arrangements for dealing with risk; and many other factors. This paper embodies a collection of principles that capture the key aspects of an inclusive labor market and which also guide the structure of this paper.

A key theme in this paper is that while there may be cases where achieving inclusivity may entail a trade-off with economic efficiency, there are important areas where achieving inclusivity is a win-win proposition: that is, where making labor markets more inclusive also enhances economic efficiency and growth. Discrimination is an important such area.

The remainder of this paper proceeds as follows. After outlining the principles of inclusivity in Section II, Section III provides measurements and stylized facts related to inclusivity in labor markets around the globe; Section IV provides a selected review of labor market policies and institutions that may enhance inclusivity; and Section V concludes.

\section{Principles OF INCLUSIVE LABOR MARKeTS}

We describe a set of four principles that serve as our guide for assessing labor market inclusiveness. In some cases, improving inclusivity along one dimension may be complementary to improvement along others, while in others, there may be trade-offs. The four principles are: (1) access, (2) fairness, (3) protection, and (4) voice. ${ }^{2}$

Access. At its simplest level, this principle stipulates that individuals should have access to employment opportunities. But more broadly, this principle also stipulates that an individual's access to specific jobs and occupations should be based on their ability to carry out the tasks associated with the activity and not on socioeconomic or demographic factors such as age, race, gender, or religion. Put differently, if the work environment is hostile to certain groups of workers, then this should be viewed as a barrier that limits access. Importantly, this principle applies not only to access to specific jobs, but also encompasses access to learning and

\footnotetext{
2 This paper focuses narrowly on features of the labor market per se. Many outcomes in life with important effects on labor market outcomes are realized prior to entering the labor market, such as the amount and quality of schooling. Such pre-labor market outcomes are outside the scope of this paper.
} 
development opportunities. Barriers to access can take many forms, including features like work arrangements. For example, if a job or occupation does not offer flexible work schedules despite it being economically feasible to do so, this would limit the access of productive individuals who require such flexibility. Similarly, not making adequate provisions that make work feasible for individuals with disabilities also serves as a barrier that limits access.

Fairness. This principle stipulates that workers should be rewarded based solely on their contributions and not based on factors such as age, race, gender or religion. Thus, an individual should not receive less than they merit based on productivity.

Protection. This principle stipulates that the labor market should provide insurance to protect individuals against negative shocks, such as temporary or permanent health shocks, or a job displacement shock due to downsizing or external trade competition. This insurance may take many forms - disability insurance, unemployment insurance, retraining programs, and many others. Viewed broadly, this principle would also extend to providing insurance to individuals who enter the labor market under poor initial conditions.

Voice. Every workplace has a large set of rules and practices that govern the range of activities that take place within it. These rules and practices describe how work is organized, how interactions take place between workers and management, and how work schedules and assignments are determined. The fourth principle stipulates that workers should have a voice in the process that determines these rules and practices. Formal collective bargaining agreements represent one means through which workers have voice, but workers may also maintain a voice without formal representation. Workers' voice can also be achieved at higher levels than the workplace through the political process.

Rather than trying to devise a single index, a useful approach to assessing the extent of inclusivity in a particular labor market is to examine the scope of departures from each of these four principles individually. In assessing these departures, it is important to assess the scope of the departure. For example, do the barriers to access reflect a widespread lack of access, or are they largely confined to a few subgroups? If workers are paid less than their productivity, does this describe the situation in general, or only of particular groups? If the departures are widespread, we will refer to them as macro departures, whereas if they are much narrower in scope, we will refer to them as micro departures. This distinction can have important implications for what sorts of policies will provide appropriate remedy, particularly for some dimensions of inclusivity. 


\section{MEASURES OF INCLUSIVITY}

In this section we briefly discuss ways in which we can use available data to shed light on the extent to which labor markets differ in terms of achieving the four principles introduced earlier.

\section{A. Access}

Household labor force surveys represent the most widely available and comparable data on labor market outcomes. A key objective of these surveys is to divide the population into three mutually exclusive groups: the employed, the unemployed and the non-participants. Data on these groups are commonly available and we discuss here how they can be used to shed light on the issue of access, while also noting some limitations of these basic data.

A key element of labor market access is the opportunity for employment. This suggests that the unemployment rate is a natural starting point; after all, in the labor market statistics individuals are unemployed if they are available for work and searching for work but not currently working. Modern theories of unemployment emphasize that some unemployment is inevitable in a dynamic economy, so one should not think that zero unemployment is the appropriate benchmark for assessing inclusivity. However, to the extent that these dynamic forces are broadly similar across economies, at least across those at similar stages of development, (large) differences in unemployment rates among countries are informative.

Figure 1 displays average unemployment rates over the period 2015-2019 for a large crosssection of countries, broken into three broad groups corresponding to categories of economic development. ${ }^{3}$ The key message from this figure is that unemployment rates vary quite dramatically across countries. These differences are particularly noteworthy for the set of advanced economies (AEs) and emerging economies (EMs), a point we shall return to. ${ }^{4}$

\footnotetext{
${ }^{3}$ We report average values over several years to focus on longer run differences that do not simply reflect business cycle fluctuations. Country groups are based on the IMF's WEO classification.

${ }^{4}$ Important variations exist not only cross-sectionally, but also over time. For example, research estimating the socalled Okun's law — which, following Okun (1962), describes the empirical cyclical relationship between economic activity and unemployment - has shown that it can vary widely across countries, including especially between advanced economies and developing countries (Furceri et al., 2019). Related research has noted that adverse economic shocks can lead to persistent (scarring) effects on unemployment (Blanchard and Summers, 1986) and economic activity (e.g., Cerra and Saxena, 2008). This broader literature is suggestive of the role that labor market policies and institutions can potentially play not just for the level of unemployment, but also for how unemployment dynamically responds to adverse shocks.
} 
Figure 1. Unemployment rate, total

(\% of total labor force, averages of 2015-19)

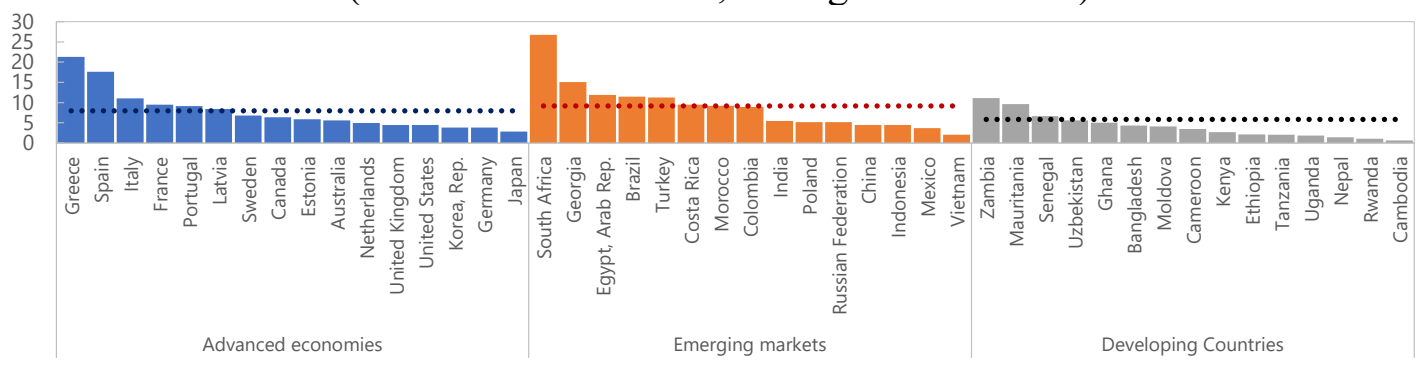

Sources: ILO and authors' calculations. Averages are calculated based on all available countries in each group, respectively, including those not listed in the chart. Country groupings are based on the IMF WEO classification.

While it is intuitively appealing to equate unemployment with a lack of access to employment, there are clearly exceptions to this rule. On the one hand, some unemployment may be voluntary in nature, in the sense that the individual has turned down some employment opportunity in favor of remaining unemployed. But on the other hand, it is important to note that an individual who desires work but does not search for work because there are no jobs available will not be counted as unemployed. For this reason, it is also of interest to examine the employment rate as a measure of opportunity. Figure 2 shows data for the employment rate that are comparable to those in the previous figure on the unemployment rate. Once again, there are striking differences across countries, but now the differences are particularly large for the less developed economies. ${ }^{5}$ An important message is that the unemployment rate may be a much less accurate indicator of access in less developed countries.

Figure 2. Employment to population ratio, total (\%) (averages of 2015-19)

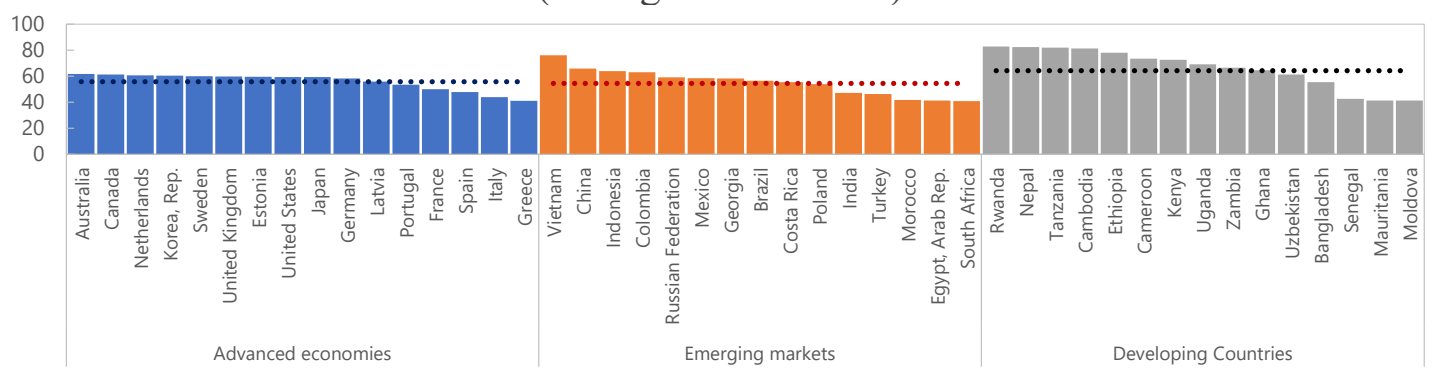

Sources: ILO and authors' calculations. Averages are calculated based on all available countries in each group, respectively, including those not listed in the chart. Country groupings are based on the IMF WEO classification.

\footnotetext{
${ }^{5}$ In the interest of space, we only present data for the overall population. Many factors can affect these aggregate numbers, including differences in demographic structure, but large differences remain even when focusing on more narrowly defined demographic groups.
} 
To pursue this further, we examine the data for participation rates across the same set of countries (Figure 3). The participation rate tells us what fraction of the population is either working or looking for work. The key feature of this figure is the large variation in participation rates, both within and across groups. While there are many factors that can give rise to differences in participation rates, such large differences, especially among countries at a similar stage of development, is strongly suggestive of limited access.

Figure 3. Labor force participation rate, total

(\% of total population ages 15-64, averages of 2015-19)

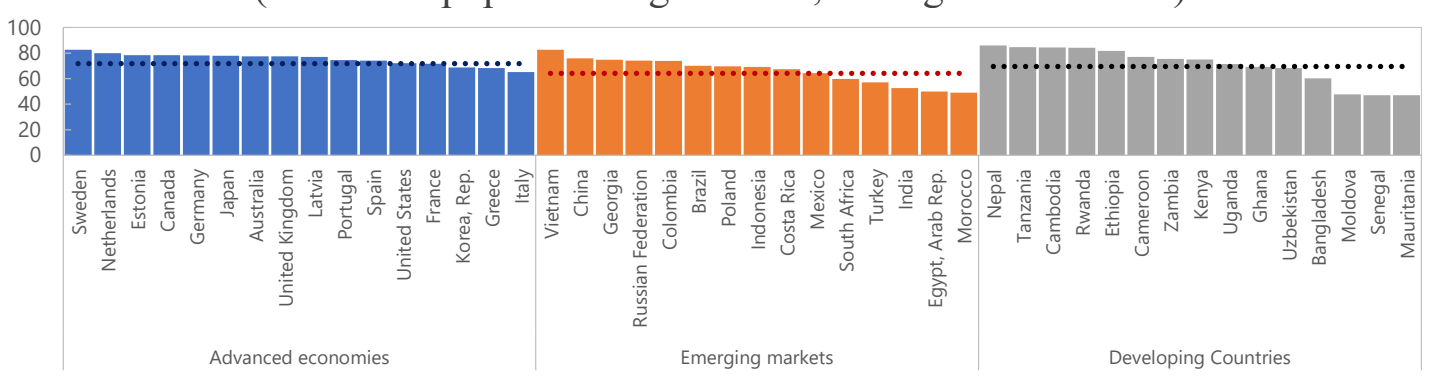

Sources: ILO and authors' calculations. Averages are calculated based on all available countries in each group, respectively, including those not listed in the chart. Country groupings are based on the IMF WEO classification.

The statistics we have presented for the aggregate labor market are best interpreted as reflecting macro departures from inclusivity. Standard labor force survey data also present these statistics for subgroups, which allows an examination of differences by gender, skill/education, age, and race/ethnicity. In the interest of space, we do not present any disaggregated data here, but we note that in many cases, differences across economies are much larger for some subgroups, even within country groupings by stage of development.

\section{B. Fairness}

One measure of fairness is whether workers are remunerated fairly. At the macro level, the labor income share has been falling in many countries over the past several decades. In AEs, labor income shares now are about five percentage points lower than they were in 1970 (Figure 4). Despite more limited data, similar trends have been observed since 1990s in emerging markets and developing economies (EMDEs), especially among the largest EMs. 
Figure 4. Evolution of the Labor Share of Income (\%)

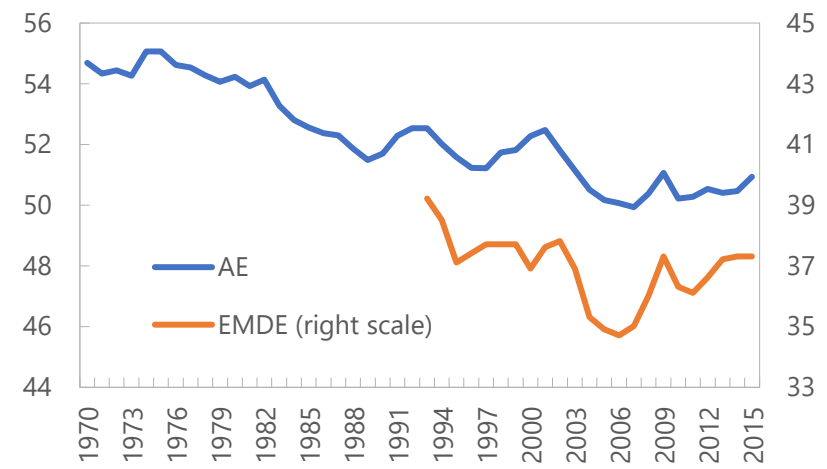

Source: IMF's World Economic Outlook (WEO) (April 2017), Figure 1.

While there are important measurement issues in constructing the labor income share, ${ }^{6}$ its downward trend indicates that average wage growth has fallen below average labor productivity growth. ${ }^{7}$ Researchers have identified several contributing factors that are technological in nature: the form of technological progress along with a relative decline in investment goods prices (IMF 2017), automation (Acemoglu and Restrepo 2018, Martinez 2018; see also Cerra et al. 2021, Chapter 5), and globalization and offshoring (Koh et al. 2000, IMF 2017, Elsby et al. 2013).

The technological factors noted in the previous paragraph would generate changes in the labor share even if labor and product markets were perfectly competitive. Another body of literature has emphasized the role of changes in monopoly and monopsony power as factors leading to changes in the labor share. ${ }^{8}$ One strand of this literature notes the emergence of "superstar firms" (OECD 2018, Autor et al. 2017, Manyika et al., 2019) that has led to rising industry concentration, leading to rising market power, higher markups and thus greater profit shares (Cerra et al. 2021, Chapter 6; Barkai 2020; Gutiérrez and Philippon 2017). Another strand has argued that deregulation of labor market institutions and weaker collective bargaining institutions have weakened the bargaining power of workers and thereby lowered wages relative to productivity (Ciminelli et al., 2020; Manyika et al., 2019; Bengtsson, 2014). In a recent paper,

\footnotetext{
${ }^{6}$ Two well-known measurement problems in the analysis of labor shares include: (1) the treatment of selfemployment income, which is often incorrectly treated as capital income (Gollin, 2002); and (2) the depreciation of capital, which should arguably be netted out from the calculation of income shares (Bridgman, 2018).

${ }^{7}$ The labor share, defined as $W \cdot H / Y$ where $W$ is compensation per hour, $H$ is hours worked and $Y$ is GDP (and hence, total income), can also be written as $W /(Y / H)$ which is in turn equal to $W / A P L$ where $A P L$ is the average product of labor. If the Marginal Product of Labor $(M P L)$ is proportional to the $A P L$ (which is the case, e.g., for a Cobb-Douglas production function with a time-invariant capital share), then changes in the labor share can be used to infer changes in the ratio of wages to marginal productivity.

${ }^{8}$ In a firm monopsony, firms can use their market power in employing labor to push wages below the marginal product of labor, collecting rents while reducing employment to below what would occur in a perfectly competitive benchmark.
} 
Gouin-Bonenfant (2021) argues that changes in the distribution of firm level productivity have effectively increased the degree of firm monopsony power in the labor market.

Changes in the labor income share are suggestive of how the experiences of workers on the whole have evolved over time. Here, we also consider whether different groups have had systematically different experiences - that is, fairness at the micro level. A large literature, going back at least to Mincer (1974), has attempted to establish whether individuals of different genders, racial, religious, or other groups have been paid significantly differently after controlling for observable characteristics that are believed to be related to productivity. ${ }^{9}$ If so, this would suggest that factors other than an individual's contribution to output play a role.

Conversely, this suggests that differences in earnings are not necessarily evidence of a lack of inclusion. For example, based on the Mincer approach, empirical findings suggest that, on average, controlling for years of experience, one additional year of schooling raises average earnings by about 10 percent (Heckman et al., 2006; and Montenegro and Patrios, 2014). That is, differences in education tend to translate into differences in earnings. There is evidence, however, that wage disparities have been widening over time across skill groups - average wages for workers with lower skill levels/educational attainment have remained nearly unchanged in real terms over the past 50-60 years, while those of workers with more than a college degree nearly doubled (Autor, 2019). Much of the rise in skill premia can be attributed to rapid globalization and technological advancements, with many new technologies facilitating automation of routine and typically lower-skill tasks, while complementing many tasks that are often completed by higher-skilled workers. ${ }^{10}$ Consistent with this, Heckman et al. (2006) estimate that the average return to schooling among males increased from about $10 \frac{1}{2}$ percent during the 1980 s to 14 percent during the 1990 s.

Mincer regressions have been used to identify differences in earnings or wages across subgroups after controlling for observable characteristics that are believed to be correlated with productivity. In particular, this method has been used to assess gender and racial wage gaps. Gender pay gaps are significant in most countries (Figure 5). Based on a recent cross-country study (ILO, 2018b), factors such as education, age, work experience, workplace characteristics, working time, occupational categories, and other labor market attributes explain little of the gender pay gap at different points of the wage distribution, suggesting that other factors are at play.

\footnotetext{
${ }^{9}$ The Mincer model (Mincer 1974) provides a useful framework for understanding differences in earnings outcomes due to differences in schooling, labor market experience, and other factors. In its simplest form, it empirically estimates the relationship between an individuals' earnings and their education levels and labor market experience. Other models in a large related literature attempt to account for other productivity-related characteristics. See, e.g., Bowles et al. (2001).

${ }^{10}$ See Cerra et al. 2021, chapter 5 for further detail.
} 
Figure 5. Median gender pay gap

(Factor-weighted gender pay gaps using hourly wages, averages of 2015-19)

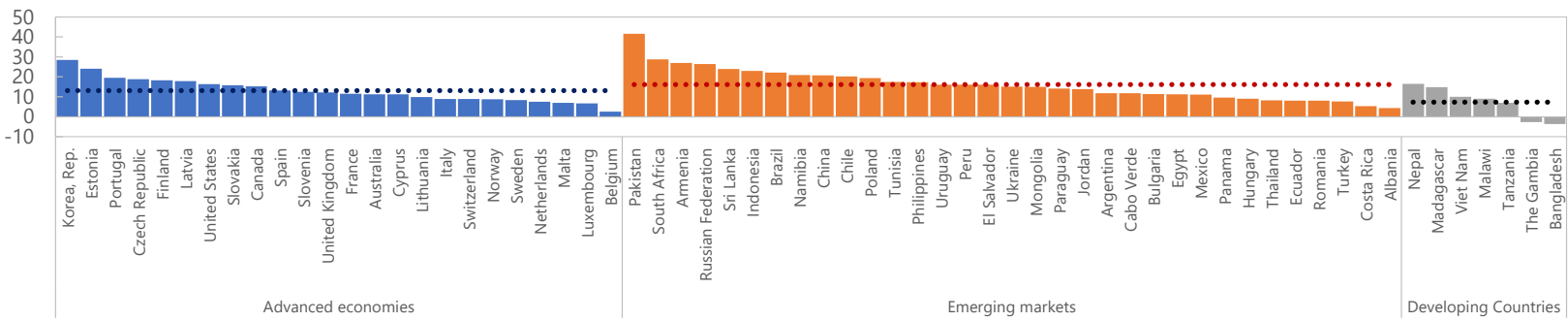

Sources: ILO and authors' calculations. Averages are calculated based on countries shown in each group, respectively. Country groupings are based on the IMF WEO classification.

Important pay gaps exist also across racial groups. Given different racial compositions, crosscountry comparisons are challenging. However, for the case of the US, Bayer and Charles (2018) find that in 2014 the median black man in the US earned significantly less than the median white man (Figure 6). In addition to comparing median wages, Bayer and Charles also calculate the black-white earning gap for all individuals in the sample, whether employed or not, i.e., including the zero earnings of non-employed individuals. This calculation effectively combines differences in access (i.e., the likelihood of being employed) with fairness (i.e., wage differences). Applying this calculation widens the gap considerably - in fact, Bayer and Charles show that in real terms, relative to white men, black men are virtually no better off in 2014 than they were in 1950 .

Figure 6. Median black male wage for every $\$ 1$ earned by white men

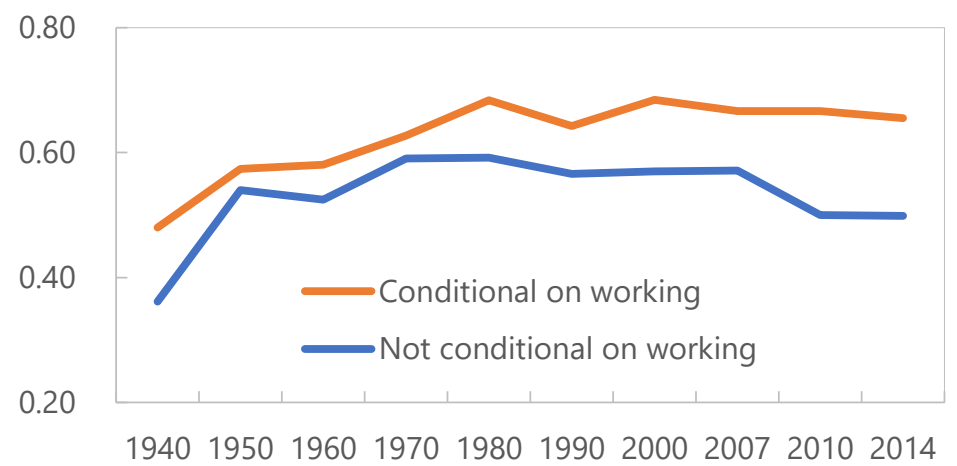

Source: Patrick Bayer and Kerwin Kofi Charles, "Divergent Paths." Note: Men aged 25-54. Real wages are measured in thousands of 1980 dollars.

\section{Discrimination}

Discrimination is an important candidate for explaining some of the pay differences that are not attributable to standard explanatory variables. It is a key challenge for policymakers striving for inclusive labor markets, often reflecting factors that originate outside the labor market (e.g., 
access to quality education). Discrimination can take many forms, ranging from individuals taking explicit actions against members of certain groups (e.g., racism) to more implicit or unintentional biases, sometimes rooted in (implicit or explicit) social norms (e.g., the notion that women should be the main childcare providers).

Increasingly, empirical work on discrimination has focused on field experiments, which are helpful in providing evidence that cannot be isolated using standard labor market data. While they leave unanswered the question as to whether the results apply more broadly, several such studies provide compelling evidence that discrimination is pervasive and important, in the US and elsewhere. ${ }^{11}$ For example, regarding gender discrimination, Goldin and Rouse (2000) assessed the extent of differential access between male and female symphony musicians. In a quasi-natural experiment, a change in hiring practices at symphony orchestras involved the move to "blind" auditions, in which the audition took place behind a screen, thereby preventing the jury from knowing the gender of the auditionee. Goldin and Rouse found that hiring was much more gender neutral when auditions were blind. More broadly, a consensus view from experimental research points to evidence of significant discrimination against women in highstatus or male-dominated jobs as well as discrimination against men in female-dominated jobs (Azmat and Petrongolo 2014). ${ }^{12}$

Other work has focused on racial discrimination. For example, Bertrand and Mullainathan (2004) assessed the extent to which race affects access to job opportunities. Their research design involved sending fictitious applications to real job openings, with applications identical except for varying names that suggested racial differences. They found large differences in callback rates: applicants with "white-sounding" names were 50 percent more likely to receive a callback than applicants with similar resumes but with "African-American-sounding" names.

Another set of studies examines the impact of bias on job performance. Glover, Pallais, and Pariente (2017) examined the performance of cashiers in a French grocery store chain. Cashiers worked with different managers on different days and their schedules were determined quasirandomly. Minority cashiers that were scheduled to work with biased managers (as determined by an implicit association test) were absent more often and were less productive than majority cashiers.

\footnotetext{
${ }^{11}$ See Bertrand and Duflo (2016) for a survey of the broader literature.

12 While research has focused on discrimination in hiring practices, one might hypothesize important general equilibrium effects in terms of how anticipated discrimination in the labor market might feed back into individuals' choices in human capital accumulation or job search. The experimental research summarized here does not offer insights on this dimension.
} 


\section{Protection}

Individuals are subject to various labor market risks, both cross-sectional and intertemporal. For example, search frictions imply that two ex-ante identical individuals may end up with different pay (e.g., Mortensen, 2003), and earnings and unemployment risk mean that two ex-ante identical individuals with initially equal pay may experience different earnings profiles over time, independent of their individual actions. In this context, Jacobson et al. (1993) have documented that the earnings of displaced workers (i.e., those losing their job for reasons unrelated to their own performance or characteristics, such as plant closings) can remain 25 percent lower than those of similar non-displaced workers even five years after displacement. ${ }^{13}$ The welfare losses of uninsured earnings risk can be large: Rogerson and Schindler (2002) calculate those associated with the earnings uncertainty of displacement on the order of up to one percent of output. Heathcote et al. (2007) consider more general types of labor market risk and calculate welfare costs that are up to an order of magnitude higher. ${ }^{14}$

Private insurance against these kinds of labor market risks is typically not available. However, there are several labor market policies and institutions that can help provide some insurance against earnings shocks that cannot otherwise be insured against. Unemployment insurance (UI) is a prime example of a government-financed public insurance system. Other policies to deal with labor market risk include employment protection legislation (EPL) which is aimed at reducing the risk of unemployment, conditional on having a job. ${ }^{15}$ These labor market policies will be discussed more in detail in Section IV.

Our goal in this subsection is to document the extent of differences in social protection that exist across countries. Later, we will discuss the efficacy of these measures and their potential adverse effects on other aspects of inclusivity. While almost all AEs have UI systems in place, they exist

\footnotetext{
${ }^{13}$ Labor market risk, including persistent scarring effects, are often also the result of aggregate shocks. For example, the empirical literature suggests that negative shocks can lead to hysteresis, that is, output losses that persist long after the initial shock. See, e.g., Cerra and Saxena (2008) for an analysis of a broad set of macroeconomic crises, and IMF (2021) in the context of COVID-19.

${ }^{14}$ All of these welfare cost estimates are large when compared to Lucas's (1987) seminal examination of the welfare gain from eliminating all consumption fluctuations, which he estimated at less than $1 / 100^{\text {th }}$ of one percent of consumption.

${ }^{15}$ EPL refers to a set of regulations regarding individual and collective dismissals and the use of fixed term rather than open-ended contracts. It includes advance notice periods or severance payments in case of individual dismissals, prior announcement and authorization for collective dismissals and limits on the length and possibility for renewal of temporary contracts. In the US, "experience rating" of unemployment insurance - where an unemployment insurance tax rate depends on the employer's history of layoffs - and strict anti-discrimination clauses - often enforced via class-action suits - have been shown to act as a dampening factor on layoffs over the business cycle (Ratner, 2013; Johnston, 2021).
} 
in only about 60 percent of EMDEs. In addition, recent estimates suggest that only about 22 percent of unemployed workers are covered by unemployment benefits (Duval and Loungani (2019) and ILO (2017)). Among those countries with an UI system, benefit coverage is much greater in AEs than in EMDEs - on average, close to half of the unemployed receive benefits in AEs, compared to less than a third in EMDEs (Figures 7 and 8).

Figure 7. Share of countries with an

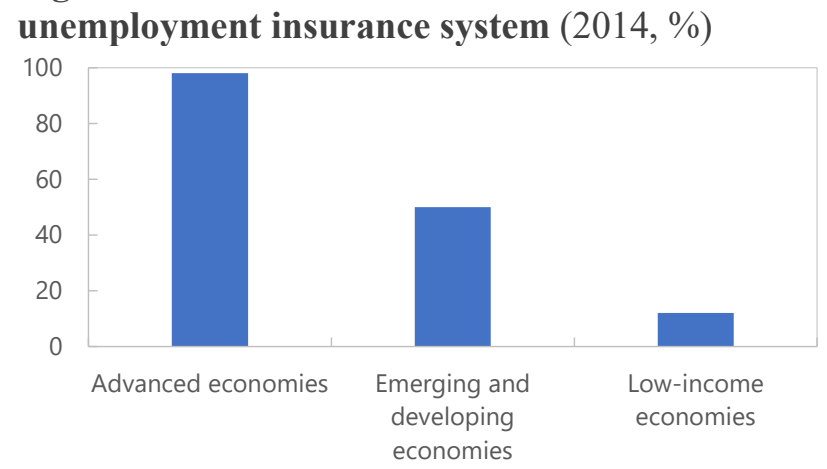

Sources: ILO Statistics and Duval and Loungani, 2019.
Figure 8. Unemployment benefit coverage (2013, percentage of unemployed workers receiving benefits)

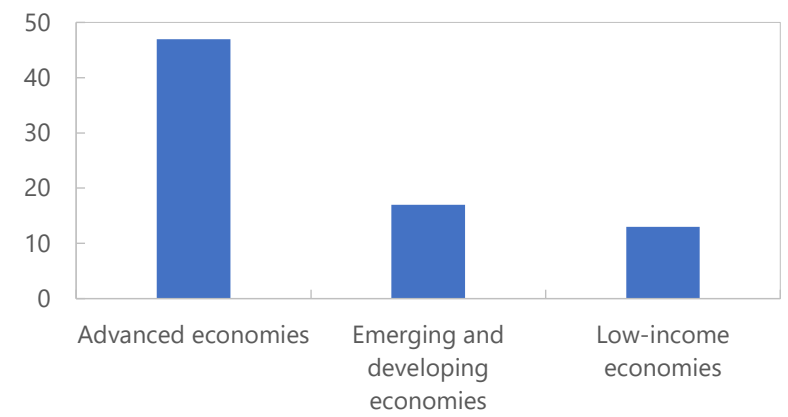

Sources: ILO Statistics and Duval and Loungani, 2019.

The stringency of EPL and the coverage and level of MWs vary widely across countries. Among OECD countries, some countries such as the Netherlands employ strict EPL measures, while others, such as Canada and the USA, impose comparatively few restrictions on job dismissals, although the US experience rating premium in unemployment insurance taxes has similar effects on dismissals (Johnston, 2021) (Figure 9). Similarly, MWs are widely used among AEs, with nearly $3 / 4$ having some MW, while only about 60 percent of EMDEs have a formal MW (Figure 10).

Figure 9. Procedural requirements for individual dismissals of regular workers (2019, Indicator score)

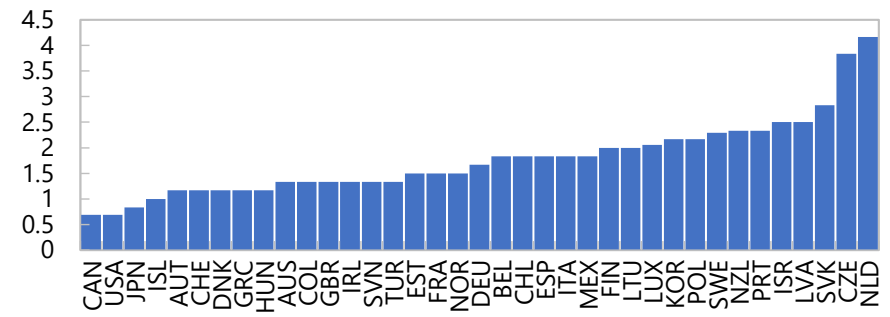

Source: OECD Employment Protection Legislation Database. Note: Range of indicator scores: 0-6. Procedural requirements consist of two components: notification procedures and time delay before notice can be given. 
Most countries also have other

complementary insurance systems, such as health, pension and disability insurance, as well as, in many cases, social welfare systems that provide a subsistence level of income. While a deeper discussion of these systems is beyond the scope of this paper (see, however, Cerra et al. 2021, Chapter 14 on health-related issues and Chapter 18 on generational issues), ILO (2017) concludes that such systems remain limited in terms of presence and coverage worldwide, and particularly in EMDEs - for example, globally only 41 percent of new mothers receive maternity benefits, while only about 28 percent of persons with severe disabilities receive disability benefits. However, Figure 11 indicates that the lack of social protection is not exclusively a matter of economic development - the most generous social protection systems in EMs exceed those at the lower end among AEs, while the least generous EMs fall short of some developing economies.

Figure 11. Proportion of population covered by social protection floors (\%) (averages of 2015-18)

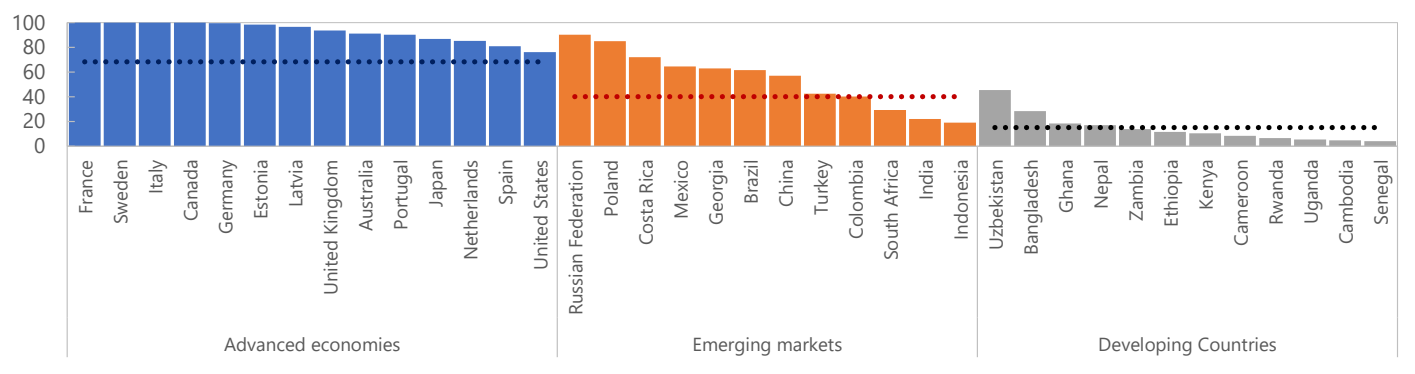

Sources: ILO and authors' calculations. Averages are calculated based on all available countries in each group, respectively, including those not listed in the chart. Country groupings are based on the IMF WEO classification.

\section{Voice}

Labor contracts - whether formal or informal - are never fully contingent and so allow for renegotiation after the realization of technological, preference or labor supply shocks. To facilitate such renegotiation and to protect match-specific investment, workers and firms often 
join trade unions and business associations, respectively, which can voice concerns over economic and social developments and engage in negotiations over wages and working conditions. Trade unions, in particular, play an important role as they can help strengthen workers' voice and their bargaining power. They have often contributed to a reduction in income disparities where they historically played an important role (Callaway and Collings, 2018; Farber et al., 2018).

Forms of engagement and representation vary depending on the country context. For instance, workers can be represented by formally recognized trade unions or informal worker associations. Similarly, firms can be part of employers' associations or be members of chambers of commerce. In addition, many countries make provisions for firm-internal working conditions and grievance mechanisms, for instance, through work councils or ombuds(wo)men. ${ }^{16}$ In many European countries, workers' wage and labor conditions are often covered by collective agreements despite not being member of a trade union (through voluntary or administrative extension of wage bargaining agreements). The labor market effects of collective bargaining are shaped to a significant degree by how bargaining takes place. In some countries, collective bargaining is centralized, with both workers and businesses are represented at the national level in tripartite structures to engage in negotiations over national development strategies. In others, bargaining is decentralized systems at the firm level, for example, with worker representatives being members of the board of certain (large) companies or organized through work councils. And in some, it takes a more intermediate form, with sectoral or occupational institutions bargaining over minimum standards for wages and working conditions for (covered) workers. In practice, collective bargaining institutions are more complex and can make clear-cut distinctions between these different types challenging. For example, while many European economies are classified as ones with predominantly sectoral bargaining, there is a great deal of variation among them in terms of extension agreements (i.e., the extent to which bargaining agreements are binding for non-participating firms), derogation (to what extent can individual firms opt out) and coordination through pattern bargaining (OECD, 2013, Table 1). ${ }^{17}$

\footnotetext{
${ }^{16}$ To the best of our knowledge, no overall encompassing overview exists for cross-country comparison of different forms of such mechanisms of voice. Most comparable information is limited to rates of trade unionization and business associations.

${ }^{17}$ The possible impact of collective bargaining institutions on wage and (un)employment outcomes was summarized by Calmfors and Driffill's (1988) "hump-shaped hypothesis" which argued that highly centralized systems (by providing macro flexibility) and decentralized systems (by providing micro flexibility) would outperform sectorlevel bargaining in terms of unemployment outcomes. This is because under centralized systems, unions would be more likely to internalize the impact of negotiated wages on overall unemployment, while under firm-level bargaining, they would be cognizant of the firm's profitability so as to avoid layoffs - either of these constraining elements would be absent under intermediate systems, thus leading to relatively higher wage outcomes and lower production and employment. In practice, the hump-shaped hypothesis has had mixed empirical success, in part reflecting the complexity of collective bargaining institutions.
} 
Empirically, trade union density and collective bargaining coverage rates are much higher on average in AEs than EMDEs, with collective bargaining covering about half of salaried employees in AE on average, compared to about one-quarter in EMDEs (Duval and Loungani, 2019), partly reflecting generally stronger organization of labor in AEs. However, trade union density, and collective bargaining coverage more generally, have been declining in most countries over recent decades, especially in comparison to business associations. For example, union density has roughly halved since 1980 in Germany, France, the UK, Austria, and the Netherlands, and it has declined substantially also in Central and Eastern European countries after the fall of central planning. ${ }^{18}$ And since the early 2000s, union density and collective bargaining coverage have declined in almost all countries, mostly as a result of a rise in employment in non-covered sectors and occupations (Figures 12 and 13). Conversely, membership in business and employer associations has remained stable in all OECD countries (Cazes et al., 2017) except Slovenia and Portugal, having successfully adapted "their organizational structure as well as their activities to the changing needs of business" (Brandl and Lehr, 2016). The decline in collective bargaining institutions may become particularly worrisome in light of the technological and organizational changes that are transforming the labor market and generating new forms of employment. Importantly, a stronger voice of organized labor at the company level could help a more equitable introduction of new technologies that would improve the longer-term prospects for productivity

\footnotetext{
${ }^{18}$ The decline in union coverage in Germany arguably was one of the reasons for the introduction of a MW in 2015. In some other countries, union density has declined more moderately, such as Spain, Belgium, Iceland and the Nordic countries. For more details, see Visser (2013) and OECD (2017).
}

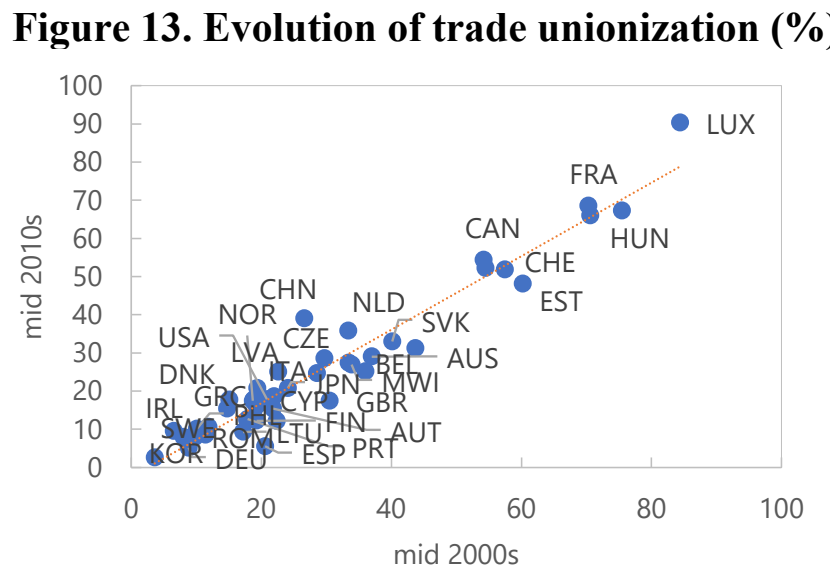

Source: ILO Statistics.

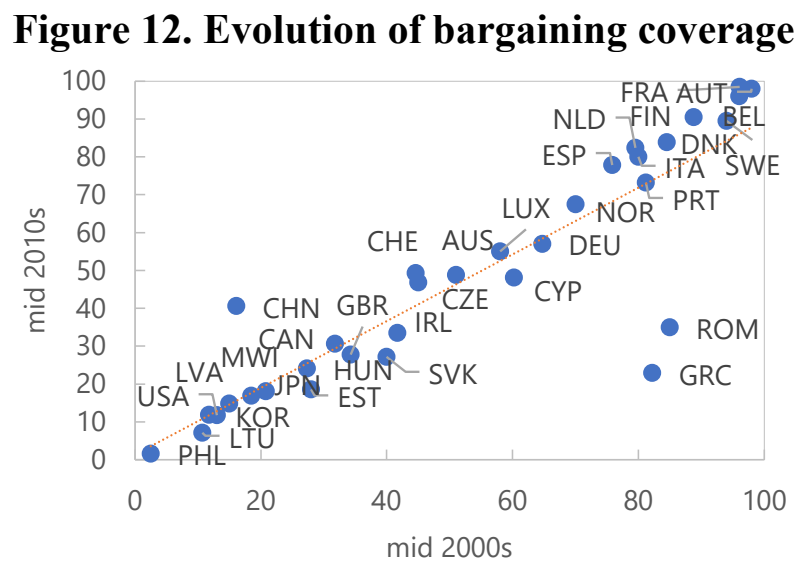

Source: ILO Statistics. 
and employment, for instance by strengthening incentives for worker training and supporting workforce reorganization (Genz et al., 2019).

\section{E. Informality as a Cross-Cutting Issue}

Informality is a cross-cutting example which touches on the aforementioned four pillars of inclusiveness. ${ }^{19}$ While informal employment in many countries is often the only avenue for individuals to gain access to employment, it is frequently in the form of low-quality jobs with low pay (fairness). ${ }^{20}$ Moreover, informal workers are insufficiently protected from risks such as job loss and health problems, and hence face higher volatility in their income (protection). Finally, informal workers are typically not organized in trade unions and hence they do not have the opportunity to protect their labor rights, associated for instance with working hours or safety regulations, as well as to influence social and economic policies (voice). ${ }^{21}$ Thus, in many EMDEs, providing formal employment opportunities is one of the main challenges to developing a more inclusive labor market, and in fact to inclusive growth more broadly. Countries characterized by a high level of informality tend to experience higher poverty and inequality (World Bank, 2019) and slower growth, with informal workers more vulnerable to shocks, since informal employment is often concentrated in low productivity activities that are more likely to be terminated in response to adverse shocks (Bacchetta et al., 2009). In this regard, informality can be a consequence of low levels of economic activity and volatile economic growth — lacking stable and productive employment opportunities and insufficient or absent social protection schemes, workers are forced into survival activities that make them particularly vulnerable to shocks. One of the main solutions to high levels of informality therefore is in many cases to create a dynamic and growing economy that provides sufficient formal employment opportunities. These broader policies are beyond the narrow scope of labor market policies (see section IV for a discussion of some labor market policies to reduce informality).

\footnotetext{
${ }^{19}$ The concept of informality ranges across several categories of activities and workers. Informality can refer to informal economic activity and informal employment. A first approach to defining informality, the enterprise-based approach, focused on the relationship between the enterprise and the government (e.g. registration status or recognition by a government). However, there are limits to this approach, since unregulated forms of employment may exist outside of informal enterprises. A second definition, resulting from the $17^{\text {th }}$ International Conference of Labour Statistician, combines the concept of informal enterprises with a concept of informal jobs (Hussmanns, 2004; Chen et al., 2005). Under this definition, paid employees are considered informal if they are not covered by any social protections. Still, the enterprise-based approach remains valid and is applied to self-employed (employers and own-account workers) who are considered to be in informal employment if the enterprise in which they work is informal. For a broader discussion, we refer to Diaz et al. (2018) and ILO (2018a).

${ }^{20}$ Workers with similar skills tend to earn more in the formal sector compared to their informal sector peers, with the wage gap widening at lower skill levels (Deléchat and Media, 2020).

${ }^{21}$ There are, nevertheless, examples of informal sector associations and trade unions are actively pursuing to reach out to informal workers. One example is WIEGO in India that has a global reach. For a strategy on how to extend social security to informal workers, see ILO (2020b).
} 
According to the ILO, two billion of the world's employed population aged 15 and over work informally, representing 61.2 percent of global employment. The incidence of informality varies across countries and is positively correlated with the level of socio-economic development. In countries at a higher level of socio-economic development, namely North America, Europe, Australia and New Zealand, informality rates are below 20 percent, while in emerging and developing countries more than 50 per cent of the labor force is informal (Figure 14). Estimates for Sub-Saharan Africa and Asia are even higher. ${ }^{22}$

Figure 14: Share of informal employment outside the agriculture (2016, \%)
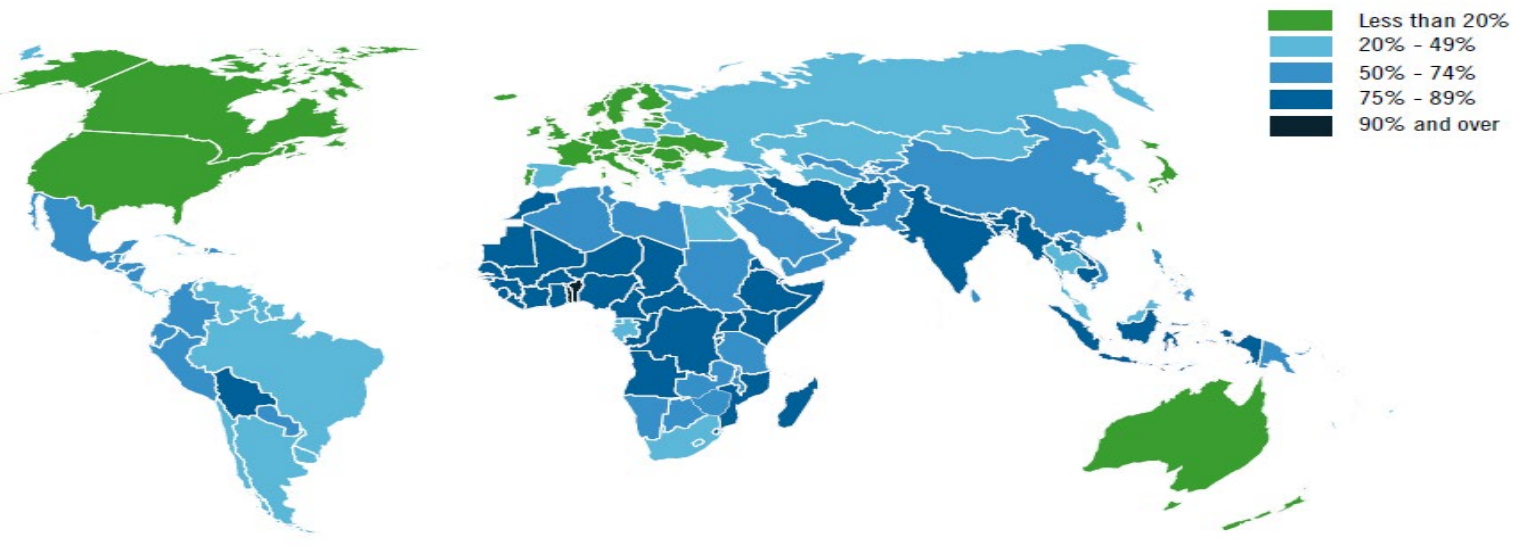

Source: International Labour Organization, available at http:/www.ilo.org/wcmsp5/groups/public/---dgreports/--dcomm/documents/publication/wems 626831.pdf and https://ilostat.ilo.org/topics/informality/

Despite the overall decline in informal employment across both AEs and EMDEs, substantial cross-country differences remain. In some countries, informal employment has increased, in contrast to much of Latin America, South Africa, Vietnam and Indonesia, where its share has been declining (OECD, 2011). ${ }^{23,24}$ The increase in certain types of informal employment observed in some countries can be seen as the reaction to a failure on the part of governments to provide proper social security or to difficulties faced by formal firms in surviving in world markets (see Bacchetta et al., 2009).

\footnotetext{
${ }^{22}$ For more details, see also Gasparini and Tornarolli (2007) and Jütting et al. (2008).

${ }^{23}$ Heintz and Pollin (2005) show that within a data set of 23 countries, 19 showed increases in informality.

${ }^{24}$ In fact, the substantial decline in informality in Latin America over the past two decades was associated with large decline in inequality (Deléchat and Media, 2020).
} 
Several factors affect the level of informality or at least are correlated with it. Informality is highly correlated with own-account workers, the agricultural sector, rural areas, women, youth and elderly populations, and low educational attainment. ${ }^{25}$

Vicious cycles may arise and further exacerbate the problem. Facing unstable income, informal workers are unlikely to invest in human capital and move to higher productivity jobs and very often they remain trapped in a vulnerable state. Moreover, high levels of informality also diminish public revenues and limit the State capacity to raise taxes that would allow it to finance public (primary and secondary) education and sustainable social security systems. ${ }^{26}$

Finally, the recent Covid-19 pandemic is likely to have a much more detrimental impact on informal workers. A large number of informal workers are engaged in manual tasks and service activities, which typically cannot be performed remotely and hence are more affected by the Covid-19 crisis.

\section{Policies For InCLUSION}

Departures from inclusivity in the labor market can arise from many factors, including demand and supply factors, cyclical or structural dynamics, and other market failures, such as incomplete insurance markets or non-competitive markets (e.g., market power). Devising the right policies to address shortcomings in labor market inclusiveness requires policymakers (1) to properly diagnose these challenges and (2) based on this diagnosis, design and implement appropriate policies.

Some standard labor market models and frameworks can be helpful in structuring such a diagnosis. For example, in some cases, it may be appropriate to consider perfectly competitive markets as a benchmark and ask if, and to what extent, market outcomes differ from such an outcome. Depending on the answer, policy implications can vary drastically: for example, in a perfectly competitive labor market equilibrium, imposing a (binding) MW will reduce employment and raise wages above the market level; by contrast, if the assessment is that firms have excessive market power (monopsony), a MW can raise employment and wages.

In other cases, it will be helpful to recognize that many labor market outcomes are shaped by frictions in the flow of job seekers and job vacancies. Job search and matching models are built

\footnotetext{
${ }^{25}$ According to UN data, women are the overwhelming majority of informal workers in developing countries, accounting for 95 (90) percent of total employment in South Asia (Sub-Saharan Africa). Own-account work refers to self-employed workers who do not have any employees.

${ }^{26}$ In EMDEs, where informality is most pervasive, government revenues are, on average, lower by 5-10 percentage points of GDP, and expenditures are lower by 4-10 percentage points of GDP than in those with the lowest levels of informality (World Bank, 2019).
} 
on this notion (e.g., Mortensen and Pissarides, 1994; Pissarides, 2000; Layard et al., 1991; Ernst and Rani, 2011). In particular, they provide a framework for examining the factors that affect the flows into and out of (un)employment, as well as the incentives for firms to create new jobs. Strong economic growth and high mobility of job seekers both across sectors and occupations allow for efficient labor reallocation and a fast return to low (equilibrium) unemployment, while frictions can, in times of recessions or when jobs are being destroyed for other reasons (e.g. automation or import competition), lead to more persistent increases in unemployment and slower adjustment to sectoral or other reallocation needs. Such frictions are particularly relevant in countries that are characterized by strong labor market segmentation arising, for instance, from lack of skills, tight regulation (e.g., occupational licensing, employment protection), lack of access to finance or lack of market access and slow growth (Fields, 2005).

Based on the diagnosis, reform success depends on the state's capacity to identify challenges properly and its ability to design and implement appropriate policy reforms. Often, policy makers lack both. Regarding the first, many countries do not possess an independent employment observatory or a well-funded (national) statistical system that would allow to identify challenges and track policy impact and progress in implementation. Part of a successful transition to an inclusive labor market therefore will include strengthening labor market information and analysis systems. ${ }^{27}$ In addition, policymakers must have the requisite economic capacity to interpret data and devise appropriate policies. Even if policy needs are properly identified, countries with limited fiscal space and a reduced capacity to mobilize resources may not be able to prioritize policies that foster inclusiveness. Lastly, implementation also, importantly, hinges on the presence of sufficient legal and institutional frameworks to enforce policies. $^{28}$

In the following, we discuss some policy measures that can help address some of the departures from inclusive labor markets suggested by the discussions so far.

\footnotetext{
${ }^{27}$ Ideally, such systems should be removed from daily policy activities to provide for a systematic analysis of the challenges; given sufficient funding; and provided with political clout. Possibilities to strengthen such a function include linking it to institutions providing social security or setting up observatory groups within a (labor) ministry. To the extent that other institutions also collect information on (local) business conditions, it is also imperative to help connecting such information across institutions (e.g., the Beige Book by the US Federal Reserve Board).

${ }^{28}$ Resource mobilization is a constant challenge in many developing economies. Setting up a national development agency can help coordinate activities across ministries, ideally by including social partners, even though such efforts to coordinate policy actions face challenges of their own, as experienced in South Africa. Cerra et al. 2021, Chapters 12 and 13 discuss in greater detail fiscal issues related to inclusive growth; Chapters 10 and 15 touch on some of aspects related to governance and political economy, respectively.
} 


\section{A. Rebalancing Market Power}

As discussed earlier, some recent research suggests that a rise in market power (firm monopsony) and a gradual erosion of effective labor market institutions, most notably a rapid decline in trade union membership and bargaining power, have played an important role in contributing to the substantial decline in labor income shares, i.e., a decline in wages relative to labor productivity. In this section we discuss some policy responses to these changes in market power. ${ }^{29}$

\section{Minimum wages}

In the presence of monopsony on local labor markets (often found in retail or hospitality services), large employers offer both employment and wages below market clearing levels to maximize their profits (Manning, 2021). Long treated as a theoretical peculiarity with little empirical relevance (Neumark and Wascher, 2008), evidence for such market power has increasingly found empirical support in recent years, both economy-wide and for specific occupations and sectors. ${ }^{30}$ Against this backdrop, the debate on using MWs as a direct way for government to create a floor for working conditions has intensified, especially among AEs. In the presence of monopsony power, MWs can constitute a win-win policy, raising inclusion and efficiency. Even in the absence of firm power, the MW is a direct distributional tool and often seen as an appealing policy option for governments to help alleviate in-work poverty, and reduce income inequality, while imposing limited direct fiscal costs. MWs also interact with social security systems including pensions (Borgshulte and Cho, 2019) and prevent the dilution of tax credits and wage subsidies (Rothstein and Zipperer, 2020). The discussion regarding the impact of MW on restoring labor market inclusiveness hinges critically on the extent and scope of market power across sectors and occupations. That is, a single MW level may not be effective to help offset general firm monopsony power that plays out across the wage distribution.

Empirical estimates of the employment impact on low-wage earners remain inconclusive (Neumark and Shirley, 2021; Dube, 2019a) and show large variation across demographic groups (Cengiz et al., 2019). ${ }^{31}$ Similar to the impact in AEs, adverse effects on employment of MWs in

\footnotetext{
${ }^{29} \mathrm{We}$ also noted that changes in the labor share could be due to the nature of technological change rather than changes in market power. Government policy might also be used to affect the nature of technological change and the extent to which labor-saving technology is adopted. Technology and policy are discussed in more detail in Cerra et al. 2021, Chapter 5.

${ }^{30}$ See Davalos and Ernst (2021) for an overview of the current state of the discussion and micro-economic evidence on the extent of monopsonistic power in the United States and Peru. The importance of firm monopsonies has also received attention in recent discussions on raising the MW in the US (CBO, 2021). See also Cerra et al. 2021, Chapter 6 on product markets and competition.

${ }^{31}$ For example, Fedoretsa and Shupe (2021) find that the introduction of a MW in Germany in 2015 raised reservation wages by up to 16 percent, but only temporarily and only at the lower end of the wage distribution.
} 
low- and middle-income countries are typically small and sometimes positive, depending on country circumstances.

The evidence does, however, point to strong positive effects on poverty alleviation (Dube, 2019b). In OECD countries, an increase in the MW is likely to result in lower wage dispersion as it tends to benefit low-skilled workers (OECD 2011) and thus could help reduce earnings inequality. In developing countries with large shares of the workforce in informal employment, where statutory MWs cannot be enforced, they often tend to spill over nevertheless, raising incomes in both formal and informal employment relationships, suggesting significant market power of employers in the formal economy (Adam and Buffie, 2020).

To maximize the effects on a reduction in poverty while limiting negative effects on jobs, the literature has identified a number of principles (Herr and Kazandziska, 2011, provide a summary). For example, a (statutory) MW should be defined in consultation with social partners to achieve poverty alleviation objectives while minimizing possible adverse employment effects, and it should be regularly monitored and revised, for example, through a representative body and based on an evaluation of the economic and social evolution, to ensure it continues to have its intended impact (ILO, 2015). ${ }^{32}$ When collective bargaining agreements have sufficient coverage, they can be also be an effective mean to fix MWs.

\section{Strengthening collective bargaining institutions}

Eroded bargaining power of (especially low-income) workers can be restored through stronger bargaining institutions. Policy intervention in this area is, however, less obvious as trade unionization relies heavily on political strategies of trade unions themselves, including whether they prefer to organize along sectoral or occupational delineations or coordinate at the regional or national level. In this regard, globalization, the rise in atypical work and a shift towards traditionally less unionized (private) service sector jobs has proved to be particularly damaging to trade unionization rates regardless of policy interventions, including in traditionally corporatist countries such as Germany where the number of trade union members halved between 1990 and 2010 (Bryson et al., 2011; Schnabel, 2013). Such a reduction, while often promoted as a move towards a more flexible labor market, can come at the cost of making industrial relations more conflictual (Addison and Teixeira, 2017). As discussed in Section III.D, trade unionization rates are low also, and especially, in developing countries where informality rates are high, despite an

\footnotetext{
32 As noted by the ILO in its Minimum Wage Policy Guide, "[s]etting and adjusting the level is perhaps the most challenging part of minimum wage fixing. If set too low, minimum wages will have little effect in protecting workers and [if] set too high, minimum wages [may] have adverse employment effects." The level that policymakers should set the minimum wage at will generally depend on country-specific factors and policy objectives, including, e.g., whether the aim of a MW is to achieve poverty objectives, address firm monopsonies, or counter discrimination.
} 
increasing effort of formal sector trade unions to reach out into the informal labor market (ILO, 2019a).

The evidence on the impact of collective bargaining and unions on (un)employment is mostly focused on AEs and is largely inconclusive. Most studies find, on balance, that unions either increase unemployment modestly or have no significant effect, although OECD data suggest that countries with high degree of coordination tend to have lower unemployment rates than others (Betcherman 2012). Consistent with theory, empirical studies also consistently find that union members and workers covered by collective bargaining earn higher wages than other workers, with a wage premium of around 5-15 percent in AEs, and up to 20 percent in some EMDEs (Betcherman 2012). Most studies show that the union wage effect is strongest for less skilled workers and is larger for women than for men, although the evidence on other typically lowwage groups, such as ethnic and racial minorities, is less clear. These effects are most prominent in systems where union density is high, and collective bargaining is centralized and/or coordinated. Thus, collective bargaining may reduce wage and income inequality (for example, Duval and Loungani, 2019), although this impact tends to be moderate due to two competing effects: unions narrow wage differentials among their members but widen disparities between unionized and non-unionized workers (Betcherman 2012).

Policy makers have several ways of strengthening collective bargaining institutions. One frequently used intervention consists of extending collective agreements reached between management and unionized workers at the company- or sectoral-level to all employees, unionized or not. ${ }^{33}$ Such administrative extensions have been shown to provide a fast and effective way of guaranteeing a protection floor, especially in low-wage sectors. They can also strengthen membership in business associations, giving employers a way to be involved in the collective bargaining process (Hayter and Visser, 2018). At the same time, extending agreements administratively can lower incentives for unionization. It can also adversely affect market competition, as some firms may have an interest in pushing for higher wage agreements if coverage extension rules can be used to raise rivals' costs (Haucap et al., 2001; Villanueva, 2015; Oesingmann, 2016). Market concentration might therefore increase, further worsening labor market imbalances that such extensions of collective agreements try to address.

An alternative but more indirect way is to bolster industrial relations at the shop floor through works councils (Rogers and Streeck, 1995). Depending on the specific institutional settings, worker representatives have to be consulted in cases of restructurings, investment or layoffs, thereby reducing labor turnover and layoffs (Hirsch et al., 2010). When combined with industry-

\footnotetext{
${ }^{33}$ See Hayter and Visser (2018) and Oesingmann (2016) for an overview of practices of administrative extension of collective agreements in Europe and some selected emerging economies.
} 
level bargaining that prevents rent seeking at the shop-floor, such works councils have been shown to raise firm-level productivity (Hübler and Jirjahn, 2003) and to speed up the introduction of new technologies (Genz et al., 2019). Nevertheless, reaping such benefits from works councils might take time and require building up trust between management and workers representatives before contributing positively to profits and wages (Mueller and Stegmaier, 2017).

Finally, some countries have managed to keep a high level of unionization through the "Ghent system," whereby trade unions rather than state agencies are responsible for administering a (voluntary) unemployment benefit system. These systems, while regulated and subsidized by the state, strengthen the ties between trade union organizations and employees, thereby increasing incentives for adherence to a union (Scruggs, 2002). At the same time, younger workers and independent contractors often opt out of such systems if they have the choice, weakening both protection and union representation (Shin and Böckerman, 2019).

\section{B. Sharing Risk}

Workers face a multitude of labor-market risks, most of which cannot (easily) be insured against. Such risks can include employment risk, technological change that makes existing skills (human capital) obsolete, and/or income risk. The absence of private insurance markets for many of these risks provides a rationale for governments to protect individuals.

Various approaches that are often chosen by governments include: (1) measures to restrict and/or regulate layoffs under certain conditions, for instance, in case of mass layoffs, but also more generally to prevent discrimination and unfair dismissals. Alternatively, (2) provision of replacement income through unemployment benefits either directly as a government-run support scheme or through subsidies to a voluntary insurance scheme. A third approach is (3) the use of labor market programs to facilitate search and retraining. The first two approaches seek to protect vulnerable households and prevent economic and social exclusion. However, they do not, per se, facilitate job mobility or provide jobseekers with the tools needed for access to, or reentry into, the labor market. Moreover, various approaches to provide protection may contribute to labor market segmentation, thus providing protection at the expense of access. The third approach aims at limiting such segmentation by strengthening incentives for mobility and provide resources to switch occupations, sectors or locations. A proper design of the three protection mechanisms and their financing is therefore required to address such a trade-off. In addition, a successful strategy needs to rely on the joint implementation of income support and activation measures. 


\section{Employment protection legislation}

As discussed in Section III.C, EPL coverage and enforcement vary significantly across countries. ${ }^{34}$ In the majority of countries, some categories of (dependent) employees are excluded. For instance, in Turkey EPL does not cover domestic workers, agricultural workers, managers/executives, as well as employees in enterprises with less than 30 workers. Australia explicitly excludes casual workers from EPL legal coverage. ${ }^{35}$ Moreover, and importantly, informally employed workers remain outside the reach of EPL.

EPL may reduce the risk of becoming unemployed for those individuals in protected jobs, but by reducing firms' incentives to create new jobs can reduce the probability for the unemployed of finding a job. Moreover, EPL has a mixed record of protecting workers against shocks. Research in AEs suggests that strict EPL reduces job destruction, as intended (Messina and Vallanti, 2007), and workers in firms with less restrictive EPL are more likely to be dismissed (Boeri and Jimeno, 2005). However, EPL can contribute to labor market segmentation between highly protected insiders and vulnerable outsiders and raises the risk of exclusion of youth and lowskilled (Betcherman 2012). Strict EPL also tends to encourage informal employment and to hinder productivity and economic growth (Bassanini et al., 2009). In the aggregate, EPL seems to slightly reduce employment, although more in EMDEs than in AEs (Duval and Loungani 2019; Betcherman 2012). Moreover, even though the impact of EPL on unemployment seems to be negligible (Heimberger, 2020), by dampening labor market turnover following an external shock, unemployment can become more persistent (Bassanini and Duval 2006).

EPLs can also affect wages. A report by the OECD (2011) argued that stricter EPLs compresses the wage distribution, and hence reduces wage inequality among the employed.

Differential EPL for different employment groups can lead to duality - in some labor markets, a significant share of workers is under temporary contracts, who are likely to receive less employer-sponsored training than workers under permanent contracts, where stricter EPL gives firms an incentive to invest more in their employees. Therefore, strict EPL reduces labor market opportunities of (more vulnerable) temporary workers relative to those under permanent contracts (Cabrales et al., 2014). Segmentation in the labor market may also lead to higher wage growth among more protected (permanent) workers, exacerbating wage inequality. Temporary contracts often involve a substantial wage penalty, for example, EU temporary workers earn on

\footnotetext{
${ }^{34}$ See Gimpelson et al. (2010) and Aleksynska and Eberlein (2016).

${ }^{35}$ Casual workers are defined as persons "who have an explicit or implicit contract of employment which is not expected to continue for more than a short period, whose duration is to be determined by national circumstance" (see ILO, 1993).
} 
average 14 percent less than regular workers (European Commission 2010), further contributing to widening wage inequality (OECD, 2011).

However, certain forms of EPL can have potentially beneficial effects. Ciminelli et al. (2020) suggest that strict EPL is associated with stronger workers' voice and hence low risk of exclusion (from employment). They argue that deregulation, by weakening workers' bargaining power, has been partially responsible for the declining labor income share in AEs. Moreover, strict EPL creates the expectation of long-lasting employment relationships and hence encourages investments by workers and firms in relationship-specific capital. Doepke and Gaetani (2020) point out that in those countries such Germany were firms cannot easily fire workers because of strict EPL, in case of turbulence shocks firms are keen to invest to maintain workers' skills and productivity. Bassanini and Ernst (2002) find that strict EPL in combination with coordinated collective bargaining might have helped innovation and productivity by stimulating the accumulation of firm-specific capital.

Alternative forms of employment protection through worker retention and furloughing schemes have attracted increased attention especially following the outbreak of the Covid-19 pandemic (OECD, 2020). Originally instituted in the chemical industry in Germany in 1910 to compensate workers for (temporary) interruptions of activity without laying them off, the German Kurzarbeit policy - which allows firms and workers to agree on hours reductions, with the shortfall in pay partially covered by the government - has been extended gradually to over all sectors and workers. Other countries have expanded similar programs as well. By raising the elasticity of hours rather than of jobs the policy has been shown to yield a significant reduction in job destruction, but also a reduction in the job-content of growth once the adverse shock is absorbed and a recovery sets in (Hijzen and Martin, 2013). Arguably, however, an overly long extension of furloughing will slow down the re-allocation of jobs, especially when the recovery is not symmetric across sectors and occupations (Cahuc, 2019).

\section{Income support and activation measures}

Unemployment insurance (UI) systems are intended to provide temporary income support during periods of joblessness, but often entail important trade-offs in balancing equity/insurance with efficiency considerations. For example, more generous UI can help offset the income losses from becoming unemployed (insurance) but may also lead to higher reservation wages and longer unemployment durations. Thus, at the most general level, UI systems should be neither too generous nor too low. ${ }^{36}$ The empirical evidence on the impact of UI benefit duration on wages

\footnotetext{
${ }^{36}$ The design of UI schemes varies significantly across countries. E.g., the level of UI benefits may be calculated as a contributions-related benefit, as a flat rate, or as a percentage of the person's last wage. Some schemes also entail a combination of these options and the application of minimum and maximum thresholds.
} 
and unemployment durations is mixed: Arni (2017) finds that longer duration of UI benefits led to higher reservation (and realized) wages in Switzerland, while others find small negative effects of extending the duration of UI benefits on realized earnings in Germany (Schmieder and Von Wachter, 2016) or modest effects in Austria (Nekoei and Weber, 2017).

However, high replacement rates, especially if paid over an extended period, may reduce jobsearch efforts and the incentive to return to work, lengthening unemployment spells, and eroding skills and labor market competencies (Van Ours and Vodopievic, 2008; Tatsiramos, 2009).

With regard to poverty and distributional effects, there does not seem to be a robust link between UI benefit levels and overall inequality in AEs (Jaumotte and Buitron, 2015). In EMDEs, the low level of coverage limits the ability of UI systems to prevent unemployment-related poverty and inequality and increases the importance of informal coping mechanisms - that is, to seek informal employment to avert poverty (OECD, 2011).

To strengthen incentives to return to work, some countries have reformed their UI systems by offering high initial replacement rates combined with a fast reduction in benefits as unemployment spells lengthen and strict obligations to accept available offers. The drawback is that a tapered scheme penalizes the most socially vulnerable groups who are the most adversely affected by unemployment, and is thus regressive (ILO, 2000a). Moreover, the prospect of a cut in unemployment benefits may prevent jobseekers from devoting time to finding jobs that match their skills, with detrimental effects on overall productivity and growth.

Indeed, recent research (Farooq et al., 2020 for the United States and Nekoei and Weber, 2017 for Austria) suggests that by providing more time for job search, extended UI benefits may significantly improve job matching. This ultimately benefits both workers and firms, another example of a 'win-win' policy. On the one hand, workers have a higher probability to find the most suitable jobs - given their education, talents, and experience - and hence earn higher wages and have greater job satisfaction and thereby lower quit rates. On the other hand, a more efficient matching process also benefits firms and the overall economy because it lowers turnover and improves productivity. Moreover, in countries where unemployment benefit schemes are limited or absent, jobseekers are keen to accept any type of work, including informal employment. This can limit their opportunities for (re-)employment in the formal sector, for instance through an erosion of skills, adverse signaling of competencies or information barriers. Therefore, welldesigned unemployment benefit schemes can strengthen incentives to work in the formal economy (Ernst, 2015).

A successful strategy proposes the combination of income support and activation measures with a reduction in EPL as part of a "flexicurity" welfare reform (Bekker and Mailand, 2019). The "flexicurity" model is characterized by the combination of three elements: generous social safety 
nets, an extensive system of activation policies and flexible hiring and firing. The most prominent example is Denmark's "flexicurity" model, which has resulted in low (long-term) unemployment rates and a high perception of job security among Danish workers (Andersen, 2011). See also Cerra et al., 2021 Chapter 21 for further discussion of the flexicurity model.

\section{Social protection}

UI benefits are only one pillar of a larger package of programs to strengthen inclusiveness and provide protection against various forms of income loss due to illness, disability or old age. Common to all are several challenges to inclusiveness that tend to create a policy trade-off between protection and access. Contributory social security systems-financed through contributions by beneficiaries and their employers-create a duality in the labor market since they automatically exclude informal and (in most cases) self-employed workers. ${ }^{37}$ Inefficiencies in social security systems often mean that the social protection benefits are small relative to contribution rates, discouraging individuals from seeking out formal employment, and similarly providing disincentives to formal job creation for firms

Therefore, a successful policy strategy to address this trade-off needs to tackle both the lack of protection and the risk of labor market segmentation. Some governments, therefore, have started to expand non-contributory systems to promote inclusiveness by extending social protection systems to informal workers not covered by any social mechanism. While this approach strengthens social protection, it further lowers incentives to work in the formal economy. A second pillar, therefore, consists of strengthening incentives to facilitate the way to formalization, for instance by broadening the tax base and lowering tax rates. In addition, a twotier social protection system could extend unemployment benefits to all workers in the formal sector including those working part-time and/or on temporary contracts, lowering incentives for jobseekers to take up an informal job. ${ }^{38}$

In recent years, many governments have taken steps towards universalizing social protections combined with increased incentives to work formally. ${ }^{39}$ Spain, for instance, lowered contribution rates for low-income workers to strengthen incentives to work formally. Similarly, Brazil, Thailand and Uruguay provide subsidies for social security contribution of self-employed workers not previously covered by the compulsory social insurance system. Philippines, Uruguay and the Republic of Korea have extended legal coverage to specific occupations, such as domestic workers and construction workers. Some countries have reduced legal barriers to

\footnotetext{
${ }^{37}$ In some countries, registered self-employed workers are also covered.

${ }^{38}$ Cirelli et al. (2021) develop a model for middle-income developing countries and show that the introduction of a UI savings account system creates incentives to work in the formal sector.

${ }^{39}$ For an exhaustive discussion on strategies to extend social security to informal workers, see ILO (2020b).
} 
formality and modified eligibility conditions on the minimum period of employment or working hours (e.g. Netherlands and Vietnam).

\section{Strengthening resilience: active labor market policies}

Social protections such as UI benefits play a key role in facilitating labor market inclusiveness by providing income support for jobless workers, but they do not necessarily equip them with the skills that they need to access better quality jobs or to achieve speedy re-entry into the labor market. In this regard, Active Labor Market Policies (ALMPs), if well designed, can equip jobseekers with the necessary support to transit to (better) job opportunities faster, thereby promoting inclusiveness. ${ }^{40}$ Therefore, a successful strategy should rely on the joint implementation of ALMPs and income support measures. The combination of the Plan de Asistencia Nacional a la Emergencia Social (National Assistance Plan of Social Emergency, $P A N E S$ ) and Trabajo por Uruguay programs is an example of such a joint strategy. On the one hand, $P A N E S$ aimed at providing monetary support to vulnerable households and preventing economic and social exclusion. On the other hand, Trabajo por Uruguay aimed at improving labor competencies of both dependent and self-employed workers and hence increasing their employability. However, the strategies have been criticized for not reaching their potential. ${ }^{41}$

Certain enabling conditions are required for the successful implementation of integrated approaches. First, a transparent and inclusive governance system is necessary for a rapid and efficient identification of the target of beneficiaries to ensure the participation of those in greatest need. Second, the involvement of social partners to address skills deficits and improve the delivery of training is important (see ILO, 2019b).

There is evidence suggesting that certain programs are more effective than others. For example, job-search assistance and training tend to work well (Card et al., 2010) and well-designed wage subsidy schemes (Card et al., 2018; Estevão 2007), while public job creation (e.g., public works programs) appears less effective in helping workers over the long run (Bown and Freud, 2019), though it could be helpful if linked with training.

\footnotetext{
${ }^{40}$ ALMPs include several tools, namely training provisions, Public Employment Service (PES) and job-search assistance, employment subsidies, start-up incentives, hiring incentives, direct job creation.

${ }^{41}$ One possible reason is the limited duration of PANES and Trabajo por Uruguay, which was capped to a maximum of five months (Escudero et al., 2020). Extending the duration of programs might have helped reduce barriers faced by beneficiaries, particularly those associated with strengthening skills. Moreover, the World Bank estimate that about 60 percent of participants of the training activities appeared to have been trained to develop nontransferable skills, i.e. skills that were specific to the project in which the individual was involved. Developing transferable skills, based on vocational training could have increased the employability of participants (World Bank, 2008).
} 
Empirical evidence for Latin American countries demonstrates that ALMPs are more successful among low-skilled workers, women and youth, especially when implemented during periods of economic expansion (Escudero, 2018 and Escudero et al., 2019). ALMPs are also associated with reduced informality: training programs increase both formal employment and earnings, while participating in the Public Employment Service increases the probability of having a formal job (Pignatti, 2016).

\section{Fighting Discrimination}

Section III on measurement has summarized a subset of a large empirical literature documenting the importance of discrimination in determining labor market outcomes. Discrimination can take many forms, resulting in unfair differences in pay, in access to certain occupations, in working conditions, and many others. While there are indications that, along key dimensions, both racial and gender discrimination has declined over the past several decades, as measured by pay gaps or occupational misallocation, it

Figure 15. Output Losses from Gender Discrimination (\%)

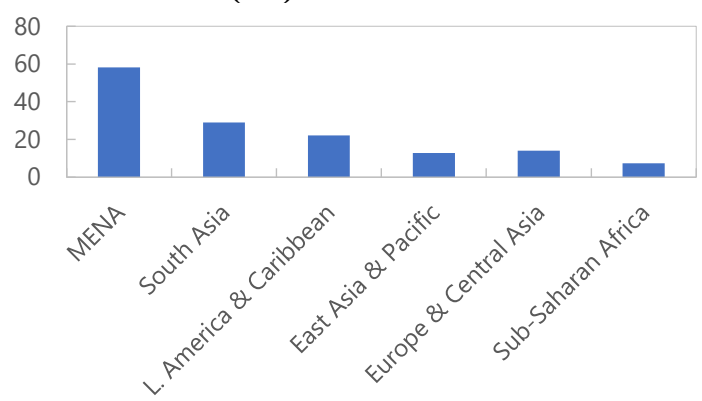

Source: ILO Statistics. remains an important obstacle to fully inclusive labor markets.

There is strong evidence that discrimination carries substantial economic costs. In their study on French grocery stores (see above), Glover, Pallais, and Pariente (2017) estimate that the performance losses due to discrimination reached up to nearly 10 percent. These losses also have an analogue at the macroeconomic level. For example, Hsieh et al. (2019) report that in 1960, over 90 percent of doctors and lawyers were white men, while by 2010 , that share had come down to just above 60 percent. ${ }^{42}$ Assuming that there are no innate differences in the underlying talent distribution among different groups, this suggests that many women and black men were not in occupations where they could contribute most productively. The authors estimate that the improved allocation of talent across occupations between 1960 and 2010 has accounted for 2040 percent of GDP growth during that time. Other research estimates benefits of reducing gender discrimination to be of a similar order of magnitude (Ostry et al., 2018 and Cerra et al. 2021,

\footnotetext{
${ }^{42}$ Anecdotally, as cited by Hsieh et al., Biskupic (2006) notes that Supreme Court Justice Sandra Day O’Connor graduated third in her class from Stanford Law School in 1952 yet could initially only find a job as a legal secretary.
} 
Chapter 16) ${ }^{43}$ See Figures 15. Thus, removing barriers to occupational choice, including through removing discrimination against workers of different race or gender, thus can have vast growth, productivity and equity benefits. Put differently, addressing discrimination is not only an ethical imperative, but is also of first-order importance from an economic perspective.

The large macroeconomic costs associated with discrimination suggest that this is an area of significant win-win outcomes: removing discriminatory occupational barriers and pay differences would benefit not only those discriminated against, but also the economy as a whole. However, while the gains from addressing discrimination are potentially large, labor market policy options are complex. Much discriminatory behavior in the labor market is rooted in cultural and social norms that are formed outside the labor market. And important elements of unequal access arise from discrimination that has taken place prior to entering the labor market, such as access to quality education and training. ${ }^{44}$

While many of the above are issues that policymakers must address more broadly and beyond the labor market, the research literature suggests some options for addressing discrimination within the labor market. For example, making discrimination illegal is an important first step. While explicit legal requirements not to discriminate do not solve the underlying sources of discrimination, they are an important necessary condition. The Equal Employment Opportunity Act of 1972 in the US is an example of such a measure forbidding discrimination against employees on the basis of race, sex, color, religion, or national origin. Chay (1998) finds that it has had a positive impact on the employment and earnings outcomes of African-American men.

The experimental studies mentioned earlier, including Goldin and Rouse (2000) and Bertrand and Mullainathan (2004), suggest that hiding the gender or racial background from recruiters can lead to less biased hiring decisions that are instead based on skills rather than other unrelated attributes, and hence to a more productive workforce. Similarly, the research by Glover et al. (2017) suggests that employers, by being more attuned to the dynamics of supervisor-supervisee relations across racial backgrounds, can achieve significantly higher productivity. While their study focused on racial aspects, similar effects may apply along the gender dimension. Implementing such policies is, again, win-win for all involved, and policymakers and social partners can play a role in shaping an environment that encourages such practices.

Lastly, quotas can play an important role in achieving desirable outcomes. They can be an easily measurable, and thus easily enforceable, policy to achieve diversity. Gender quotas in particular

\footnotetext{
${ }^{43}$ Relatedly, Page (2017) argued that diversity in teams carries a "bonus" in that their collective decision-making exceeds that of the group members' individual decision-making ability.

${ }^{44}$ Among many examples, provision of public or subsidized childcare facilities could encourage higher female labor force participation with potentially large gains in terms of output (see Cerra et al. 2021, Chapter 16).
} 
have been increasingly adopted by many companies across the globe. In the case of European companies who implemented gender quotas on their corporate boards, Kuzmina and Melentyeva (2020) find that these companies experienced increases in firm value, suggesting that (gender) diversity and shareholder interests can go hand in hand-yet another win-win. ${ }^{45,46}$

\section{Addressing Labor Market Segmentation (Informality and Duality)}

As discussed in Section III. E, informality is one of the main obstacles to a more inclusive labor market in many countries. Policy solutions to reduce informality and labor market segmentation need to address their country-specific root causes (Loayza, 2018). Frequently, stringent and burdensome regulation, such as strict labor regulations, high (marginal) taxes, and complicated tax payment procedures (Loayza et al., 2006; Schneider, 2004; Perry et al., 2007), are a key cause of informality. A second cause is low institutional quality, such as corruption, weak rule of law, or lack of accountability, and low trust in institutions (Loayza, 2007; Torgler and Schneider, 2007; Van Elk et al., 2014). Finally, a lack of integration with the global economy, low educational levels and related low levels of productivity among formal sector firms translate into low gains from becoming formal (Bacchetta et al., 2009; de Paula and Scheinkman, 2007; Perry et al., 2007; Jütting et al., 2008). Three key policy areas include strengthening labor productivity, tax measures and administrative measures.

\section{Encouraging structural change}

Many factors prevent faster structural change towards high-productive, formal employment-in addition to weak overall economic demand, a lack of an educated workforce and low managerial competence are often to blame (Loayza, 2018; Bloom et al., 2017). Frequently, low educational attainment translates into young workers not being able to enter the labor market other than through informal jobs, significantly reducing their long-term prospects (Shehu and Nilsson, 2014).

Those shifting towards self-employment or entrepreneurship lack the skills and experience to create sustainable businesses. Overall, informal workers - whether self- or dependent employed - have significantly lower educational levels, preventing them from accessing high-productive, formal jobs (Maurizio and Vazquez, 2019). General (public) investment in education

\footnotetext{
${ }^{45}$ In the US state of California, a 2018 bill requires public companies with headquarters in California to name certain minimum number of female directors (varying by firm size) to their boards (Groves, 2019).

${ }^{46}$ The policies listed here are of course not exhaustive, and standard labor market policies may also have an impact on discrimination. For example, Derenoncourt and Montialoux (2020) have argued that the extension of the federal minimum wage coverage under the 1966 Fair Labor Standards Act affected especially industries in which black workers were more strongly represented - the authors find that the broader minimum wage coverage lowered racial earnings gaps while finding no significant employment effects.
} 
infrastructure, quality teaching and the expansion of vocational training systems can help increase educational attainment and provide more opportunities for workers to transit to formal jobs (see also Cerra et al. 2021, Chapter 14 on education for inclusive growth). This can include recognizing educational investment provided by the informal economy itself to facilitate occupational transition. Moreover, active labor policies and job reinsertion programs through (re)training can contribute to facilitate the transition to formalization both on the current job and through job switch (Card et al. 2010 and 2018).

\section{Taxation}

An efficient tax system is an important tool for addressing rising inequality and informality and restoring robust economic growth. Taxation is a potential tool to lessen the costs of operating in the formal sector, since formality choices are highly elastic with respect to marginal tax rates.

Reducing the tax rate on formal businesses eases the migration of entrepreneurs from informal into formal activity, where productivity is higher, with positive effect on output and economic efficiency. ${ }^{47}$ Higher tax rates among firm-owners induce not only substantial movements to the informal sector, but also under-reporting of taxable earnings and income shifting to tax-favored business forms, which may ultimately lead to inefficient allocation or resources. ${ }^{48}$ Lowering payroll taxes is also a potential lever to increase formal employment and extend social insurance coverage among the labor force, although the effects may vary across countries. ${ }^{49}$

If informality is voluntary, lower tax rates should reduce firms' incentives to enter the informal sector. However, even if informality is involuntary, lower tax rates could reduce informality by encouraging formal sector firms to expand employment and create more formal jobs. The empirical literature suggests that the best approach to reduce the size of the informal sector is using taxation to reduce the costs of being formal and create the right incentives for companies and workers intending to switch to the formal sector.

Some countries in Europe have undertaken reforms to strengthen formalization. For example, reduced tax rates for low-wage earners (e.g. in Belgium, Bulgaria, the Netherlands and France), as well as tax exemptions and reductions in sectors that rely on undeclared work (e.g., in Hungary, Sweden, Belgium and France).

\footnotetext{
${ }^{47}$ For a case study on the Russian Federation, we refer to Slonimczyk (2012), while for a case study on Brazil see Araujo and Rodrigues (2016).

${ }^{48}$ See Waseem (2018) for an analysis of the Pakistani tax reform introduced in 2009.

${ }^{49}$ Pagés (2017) discusses pros and cons of payroll tax cuts in developing countries and analyzes the circumstances under which payroll tax cuts can pave the way to formalization.
} 
Some emerging economies, especially in Latin American countries, have also implemented policies aiming at removing obstacles to formalization, such as simplification to registration procedures and tax simplifications for small businesses.

Brazil is an illustrative example of an emerging country which, starting form high level of informality in the late 1990s, has adopted a set of policy initiatives to facilitate the move to formality. The SIMPLES and SUPERSIMPLES programs, launched in 1996 and 2006 respectively, aimed at reducing the costs of formalization through a simplification and a reduction of tax rates and tax regulations for Brazilian micro firms with no more than five paid employees - most prevalent in the informal economy. Since the SUPERSIMPLES came into force in July 2007, some 9 million businesses have joined this system of taxation and the formality rate has increased by 11 percentage points (see Fajnzylber et al., 2011).

Another example is the Monotax (or Monotributo) implemented in 1998 in Argentina. Monotax is a simplified tax collection/payment scheme for small taxpayers. People covered by the Monotax regime are entitled to the same social security benefits as salaried workers. The Monotax has proven to be an effective tool for the formalization of micro- and small enterprises, as well as for the extension of social security coverage to independent workers, especially women. While these types of programs could help foster formalization, they have their limits as they could hinder growth opportunities in EMs, since they increase the incentives for small enterprises to remain small (see Hsieh and Olken, 2014).

In the same vein, tax reforms were implemented in Colombia in 2012 with the aim to increase employment and, in particular, formal employment. The reforms reduced payroll taxes for those with less than 10 employees and for self-employed who hired two employees or more. Empirical evidence suggests that the probability of formal employment and the likelihood of transitioning into registered employment increased for the affected groups after the reform (Kugler et al., 2017).

A more cautious view is provided by Langot et al. (2019), who analyze the effectiveness of a budget-neutral tax reform (that aims to reduce the tax burden for small enterprises) in fostering formalization. They find that tax policies might play only a minor role in improving formalization rates, especially in emerging countries. To reduce the incidence of informality, tax policy interventions should go hand in hand with other social protection policies as discussed earlier, and with administrative policies, which is discussed next. 


\section{Administrative (E-Formality) Policies}

Administrative policies should support and strengthen the effectiveness of policies towards formalization by enhancing enforcement, promoting information sharing and elevating awareness, as well as establishing efficient and transparent administrative processes.

New technologies can enhance the impact of policies addressing informality. In recent years, an increasing number of governments have started promoting the application of new technologies. These so-called "e-formality" policies facilitate development of partnerships and sharing of information among tax, social security and employment institutions, which ultimately simplify the transition to formal employment (Chacaltana et al., 2018).

An example of e-formality tools is the development of electronic solutions to facilitate tax filing and collection (e.g. e-Tax in Estonia), as well as to reduce time and costs for business registration (e.g. one-stop shops, such as Ventanilla Única Empresarial created in Colombia in 2017).

However, the registration of new firms does not necessarily imply the formalization of their workers (Deelen, 2015). Therefore, a complementary tool is the electronic registration of workers (e.g., the eSocial project launched in Brazil in 2007 or the Electronic Payroll solution created in Peru in 2006 to replace the manual reporting of private business payrolls), as well the development of electronic solutions, such as mobile apps, to simplify payment of social security contribution, especially for domestic workers. New technologies may also be used to enhance labor inspections (e.g. in the United Arab Emirates or the Digital Inspector scheme launched in Argentina in 2003).

Another aspect under which new technologies can contribute to formalization is improving access to information on and awareness of workers' human and social rights. In many countries, a large majority of workers in the informal economy has a low level of education and is often unaware of what social protection schemes are available to them and how they can access such schemes. Raising awareness is a catalyst for the extension of social security to the informal economy. Many countries have recently become more active in informing their members about their contribution records and entitlements. Turkey provides an illustrative example in this respect. Since 2012, an information system, combining the databases of three different social security institutions, allows users to obtain quick access to information on pension and health insurance status, registration and premiums by using simply their citizenship identification number (ILO, 2019b).

Finally, tracking transactions is another important tool for the transition to the formal economy, since operators in the informal economy tend to use cash, because of their limited access to 
formal financial services and/or with the purpose to avoid paying taxes. ${ }^{50}$ For instance, the Government of the Republic of Korea gives an incentive - in the form of a tax deduction in income tax - to those people reaching a certain amount in credit card transactions. Alternatively, some countries impose penalties instead of an incentive to discourage cash transactions. In Greece, for instance, taxpayers incur a penalty if they do not make enough electronic payments.

\section{CONCLUSION}

The labor market plays a key role in shaping the extent of inclusivity in the overall economy. While measuring inclusivity presents challenges, we have identified several dimensions along which there is substantial scope for improving inclusivity. We close this paper by summarizing what we view as the four key takeaways for policy makers concerned with increasing the inclusivity of the labor market.

First, there is no uniform set of policy recommendations. Importantly, inclusivity is a multidimensional concept. The departures from inclusivity may differ across economies, and different economies may place different weights on the different dimensions of inclusivity. Drafting a course of action requires both assessing the various departures from inclusivity and assigning weights to the different dimensions of inclusivity.

Second, policy makers will often face important tradeoffs in terms of achieving the various dimensions of inclusivity. For example, as we have argued, employment protection may provide protection for currently employed workers while at the same time it diminishes access for young workers entering the labor market.

Third, and related, policy makers should view policies as a bundle and not individually. Some policies are substitutes while others are complements. Thus, policies should be assessed as part of a package and not in isolation. The Danish system of flexicurity stands out as an example of a package of policies that work together.

Fourth, departures from inclusivity occur both at the micro and the macro level. Many standard policy tools are best suited to addressing problems that are macro in scope, so addressing micro departures may require more novel approaches.

We close with two additional remarks. First, our analysis has focused somewhat narrowly on what happens in the labor market. But it is critical for policy makers to understand that much of what happens in the labor market is strongly influenced by outcomes and events outside of the labor market. Inequality in access to quality schooling translates almost directly into inequality

${ }^{50}$ See also Cerra et al. 2021, Chapter 4 on financial inclusion. 
of access to opportunities in the labor market. Cultural norms or discriminatory practices outside of the labor market will similarly translate into departures from inclusivity in the labor market.

Second, many labor market outcomes reflect changes in technology. While some aspects of technological change might best be viewed as exogenous, we think that an important area for future work is to understand how policy settings influence the extent and nature of technology adoption. Some tax policies, for example, might implicitly encourage firms to replace low skill labor with machines. As the impact of technology continues, we think it will become increasingly important to think about the potential for policy to shape the nature of technological innovation and adoption. 


\section{REFERENCES}

Acemoglu, Daron and Restrepo, Pascual. 2018. "The Race between Man and Machine: Implications of Technology for Growth, Factor Shares, and Employment," American Economic Review, Vol. 108, No. 6, June 2018, pp. 1488-1542

Adam, C. S. and Buffie, E. F. 2020. "The minimum Wage Puzzle in Less Developed Countries: Reconciling Theory and Evidence,” IMF Working Paper No. 20/23 (Washington, DC.).

Addison, J. T. and Teixeira, P. 2017. "Strikes, employee workplace representation, unionism, and trust: Evidence from cross-country data," IZA Discussion Paper No. 10575.

Aleksynska, Mariya and Eberlein, Friederike. 2016. "Coverage of Employment Protection Legislation”, IZA Journal of Labor Policy, ISSN 2193-9004, Springer, Heidelberg, Vol. 5, Iss. 17, pp. 1-20.

Andersen, T. M. 2011. "A Flexicurity Labour Market in the Great Recession: The Case of Denmark”, IZA Discussion Papers 5710, Institute of Labor Economics (IZA).

Araujo, J. and Rodrigues, M. 2016. "Taxation, Credit Constraints and the Informal Economy”, EconomiA, Vol. 17, pp. 43-55.

Arni, P. 2017. "What Drives Wage Effects of Unemployment Benefits? Evidence from Natural Experiments and Reservation Wage Data," Beiträge zur Jahrestagung des Vereins für Socialpolitik 2017: Alternative Geld- und Finanzarchitekturen. Conference paper. Available at: https://www.econstor.eu/handle/10419/168154

Autor, D, D Dorn, L Katz, C Patterson and J Van Reenen. 2017. "The Fall of the Labor Share and the Rise of Superstar Firms", IZA Discussion Paper 10756.

Azmat, Ghazala and Petrongolo, Barbara. 2014. "Gender and the Labour Market: Evidence from Experiments," VoxEU Column, June 7, 2014. Available at: https://voxeu.org/article/gender-and-labour-market

Bacchetta, M.; Ernst, E.; and Bustamante, J. 2009. "Globalization and Informal Jobs in Developing Countries. A Joint study of the International Labour Office and the Secretariat of the World Trade Organization, Geneva.

Barkai, Smicha. 2020. "Declining Labor and Capital Shares”, The Journal of Finance, Vol. 75, Issue 5, pp. 2421-2463, April 2020. Available at:

https://onlinelibrary.wiley.com/doi/abs/10.1111/jofi.12909

Bassanini, Andrea and Duval, Romain. 2006. "Employment Patterns in OECD Countries:

Reassessing the Role of Policies and Institutions", OECD Social, Employment and Migration Working Papers, No. 35. June 9, 2006. OECD Publishing, Paris. Available at: https://doi.org/10.1787/702031136412

Bassanini, A. and Ernst, E. 2002. "Labour Market Regulation, Industrial Relations and Technological Regimes: A Tale of Comparative Advantage," Industrial and Corporate Change, Vol. 11, Nr. 3, pp. 391-426.

Bassanini, A.; Nunziata, L.; and Venn, D. 2009. "Job Protection Legislation and Productivity Growth in OECD Countries [Appropriate Growth Policy: a Unifying Framework]," Economic Policy, CEPR; CES; MSH, Vol.24(58), pages 349-402. 
Bayer, Patrick and Kerwin Charles. 2019. "Divergent Paths: A New Perspective on Earnings Differences Between Black and White Men Since 1940," The Quarterly Journal of Economics, Volume 133, Issue 3, August 2018, Pages 1459-1501. Available at: https://doi.org/10.1093/qje/qjy003

Bekker, S. and Mailand, M. 2019. "The European Flexicurity Concept and the Dutch and Danish Flexicurity Models: How Have they Managed the Great Recession?," Social Policy Administration, Vol. 53, Nr. 1, pp. 142-155.

Bengtsson, Erik. 2014. "Do Unions Redistribute Income from Capital to Labour? Union Density and Wage Shares since 1960," Industrial Relations 45:5 (September). First published: 12 July 2014. Available at: https://doi.org/10.1111/irj.12065

Bertrand, Marianne and Mullainathan, Sendhil. 2004. "Are Emily and Greg More Employable Than Lakisha and Jamal? A Field Experiment on Labor Market Discrimination." American Economic Review, 94 (4):991-1013.

Bertrand, Marianne and Duflo, Esther. 2016 "Field Experiments on Discrimination," NBER Working Paper No. 22014. Available at: http:/www.nber.org/papers/w22014

Betcherman, Gordon. 2012. "Labor Market Institutions: A Review of the Literature," Policy Research Working Paper No.6276. November 2012. World Bank, Washington, DC: World Bank. Available at: https://openknowledge.worldbank.org/handle/10986/16382

Biskupic, Joan. 2006. “Sandra Day O'Connor: How the First Woman on the Supreme Court Became Its Most Influential Justice,” HarperCollins.

Blanchard, Olivier, and Lawrence Summers. 1986. "Hysteresis and the European unemployment problem," NBER Macroeconomics Annual 1986, Volume 1 (MIT Press).

Bloom, N.; Sadun, R.; and Van Reenen, J. 2017. "Management as a Technology?,” NBER Working Paper No. 22327.

Boeri, T. And Jimeno, J. F. 2005. "The Effects of Employment Protection: Learning from Variable Enforcement”, European Economic Review, Vol. 49 (8), pp. 2057-2077.

Borgschulte, M. and Cho, H. 2019. "Minimum Wages and Retirement," ILR Review, Vol. 73, No. 1, pp. 153-177.

Bowles, Samuel; Gintis, Herbert; and Osborne, Melissa. 2001. "The Determinants of Earnings: A Behavioral Approach," Journal of Economic Literature, 39 (4): 1137-1176. Available at: https://www.aeaweb.org/articles?id=10.1257/jel.39.4.1137

Bown, C. and Freud, C. 2019. "Active Labor Market Policies: Lessons from Other Countries for the United States", Peterson Institute for International Economics Working Paper No. 192 .

Brandl, B. and Lehr, A. 2016. "The Strange Non-Death of Employer and Business Associations: An Analysis of their Representativeness and Activities in Western European Countries," Economic and Industrial Democracy, 1-22.

Bridgman, Benjamin. 2018. "Is Labor's Loss Capital's Gain? Gross versus Net Labor Shares," Macroeconomic Dynamics 22:8, December 2018, pp. 2070 - 2087. 
Bryson, A.; Ebbinghaus, B.; and Visser, J. 2011. "Introduction: Causes, Consequences and Cures of Union Decline," European Journal in Industrial Relations, Vol. 17, No. 2, pp. 97-105.

Cabrales, A.; Dolado, J. J.; and Mora, R. 2014. "Dual Labour Markets and (Lack of) On-The-Job Training: PIAAC Evidence from Spain and Other EU Countries", CEPR Discussion Papers 10246, C.E.P.R. Discussion Papers.

Cahuc, P. 2019. "Short-time work compensation schemes and employment", IZA World of Labor, Institute of Labor Economics (IZA), pages 1-11.

Callaway, B. and Collings, W. J. 2018. "Unions, Workers, and Wages at the Peak of the American Labor Movement," Explorations in Economic History, Vol. 68, pp. 95-118.

Calmfors, Lars and Driffill, John. 1988. "Bargaining Structure, Corporatism and Macroeconomic Performance,” Economic Policy, Vol. 3, No. 6 (Apr. 1988), pp. 14-61.

Card, D.; Kluve, J.; and Weber, A. 2010. “Active Labour Market Policy Evaluations: A MetaAnalysis”, Economic Journal, Royal Economic Society, vol. 120(548), pages 452-477, November.

Card, D.; Kluve, J.; and Weber, A. 2018. "What Works? A Meta Analysis of Recent Active Labor Market Program Evaluations", Journal of European Economic Association 16, no. 1, pp. 894-931.

Cazes, Sandrine; Garnero, Andrea; and Martin, Sébastien. 2017. "The State of Trade Unions, Employer Organisations, and Collective Bargaining in OECD Countries," VoxEU Column, July 10, 2017. Available at https://voxeu.org/article/trade-unions-employerorganisations-and-collective-bargaining-oecd-countries

Cengiz, D.; Dube, A.; Lindner, A.; and Zipperer, B. 2019. "The Effect of Minimum Wages on Low-Wage Jobs", The Quarterly Journal of Economics, Volume 134, Issue 3 pp. 14051454.

Cerra, V., B. Eichengreen, A. El-Ganainy, and M. Schindler, (Eds.). 2021 (forthcoming). How to Achieve Inclusive Growth. Oxford University Press and IMF.

Cerra, Valerie and Saxena, Sweta. 2008. "Growth Dynamics: the Myth of Economic Recovery," The American Economic Review, 98, 439-457.

Chacaltana, J.; Leung V.; and Lee, M. 2018. "New Technologies and the Transition to Formality: The Trend Towards E-Formality”, ILO Employment Policy Department Working Paper 247, International Labour Organization.

Chay, Kenneth Y. 1998. "The impact of federal civil rights policy on black economic progress: Evidence from the Equal Employment Opportunity Act of 1972," Industrial and Labor Relations Review 51(4), 608-632.

Chen, M. A.; Vanek, J. F.; Lund, F.; Heintz, J.; Jhabvala, R.; and Bonner, C. 2005. "Progress of the World's Women 2005: Women, Work, and Poverty," United Nations Development Fund for Women (UNIFEM), New York

Ciminelli, Gabriele; Duval, Romain; and Furceri, Davide. 2020. "Employment Protection Deregulation and Labor Shares in Advanced Economies," Review of Economics and Statistics, forthcoming. Available at: https://doi.org/10.1162/rest_a_00983. 
Cirelli, F.; Espino, E.; and Sanchez, J. M. 2021. "Designing Unemployment Insurance for Developing Countries", Journal of Development Economics, Volume 148.

Congressional Budget Office (CBO). 2021. "The Budgetary Effects of the Raise the Wage Act of 2021," Congressional Budget Office, February 2021. Available at:

https://www.cbo.gov/publication/56975

Davalos, J. and Ernst, E. 2021. How has labour market power evolved? Comparing labour market monopsony in Peru and the United States, ILO Working Paper (Geneva), forthcoming.

Deelen, L. (ed.). 2015. Políticas para la formalización de las micro y pequeñas empresas en América Latina (Santiago, International Labour Office).

Deléchat Corinne and Media, Leandro. 2020. What is the informal economy? Finance and Development, December 2020, IMF. Available at https://www.imf.org/external/pubs/ft/fandd/2020/12/what-is-the-informal-economybasics.htm.

Derenoncourt, Ellora and Montialoux, Claire. 2020. "Minimum Wages and Racial Inequality," The Quarterly Journal of Economics, Volume 136, Issue 1, February 2021, Pages 169228. Available at: https://academic.oup.com/qje/article/136/1/169/5905427

De Paula, A. and Scheinkman, J. 2007. "The Informal Sector." Second version. PIER Working Paper 07-035.

Diaz, J. J.; Chacaltana, J.; Rigolini, J.; and Ruiz, C. 2018. "Pathways to Formalization: Going beyond the Formality Dichotomy”, World Bank Policy Research Working Paper No. 8551.

Doepke, M. and Gaetani, R. 2020. "Why Didn't the College Premium Rise Everywhere? Employment Protection and On-the-Job Investment in Skills", mimeo.

Dube, A. 2019a. Impacts of Minimum Wages: Review of the International Evidence. (London, HM Treasury). Available at: https://www.gov.uk/government/publications/impacts-ofminimum-wages-review-of-the-international-evidence

Dube, A. 2019b. "Minimum Wages and the Distribution of Family Incomes," American Economic Journal: Applied Economics, Vol. 11, No. 4, pp. 268-304.

Duval, Romain and Loungani, Prakash. 2019. "Designing Labor Market Institutions in Emerging Market and Developing Economies: Evidence and Policy Options," IMF Staff Discussion Note 19/04. May 21, 2019. Washington DC: IMF. Available at: https://www.imf.org/en/Publications/Staff-DiscussionNotes/Issues/2019/05/15/Designing-Labor-Market-Institutions-in-Emerging-andDeveloping-Economies-Evidence-and-Policy-46855

Elsby, M.; Hobijn, B.; and Sahin, A. 2013. "The decline of the U.S. labor share”, Brookings Papers on Economic Activity, Fall.

Ernst, E. and Rani, U. 2011. "Understanding Unemployment Flows," in Oxford Review of Economic Policy, Vol. 27, Nr. 2, pp. 268-294. 
Ernst, E. 2015. "Supporting jobseekers: How unemployment benefits can help unemployed workers and strengthen job creation", International Social Security Review, Vol. 68, $3 / 2015$.

Escudero, V. 2018. “Are Active Labour Market Policies Effective in Activating and Integrating Low-Skilled Individuals? An International Comparison”, IZA Journal of Labor Policy, Springer;Forschungsinstitut zur Zukunft der Arbeit GmbH (IZA), Vol.7(1), pages 1-26, December.

Escudero, V.; López Mourelo, E.; and Pignatti, C. 2020. "Joint Provision of Income and Employment Support: Evidence from a Crisis Response in Uruguay”, World Development, Elsevier, Vol.134(C).

Escudero, V.; Kluve, J.; López Mourelo, E.; and Pignatti, C. 2019. “Active Labour Market Programmes in Latin America and the Caribbean: Evidence from a Meta-Analysis", The Journal of Development Studies, 55:12, 2644-2661.

Estevão, M. 2007. “Labor Policies to Raise Employment”, IMF Staff Papers, Palgrave Macmillan, vol. 54(1), pp. 113-138.

European Commission. 2010. "Employment in Europe 2010," Chapter 3: Youth Segmentation in EU Labor Market. Available at: https://ec.europa.eu/employment social/eie/chap3 en.html

Faber, H. S.; Herbst, D.; Kuziemko, I.; and Naidu, S. 2018. "Unions and Inequality Over the Twentieth Century: New Evidence from Survey Data," National Bureau of Economic Research Working Paper no. 24587.

Fajnzylber, P.; Maloney, W. F.; and Montes-Rojas, G. W. 2011. "Does Formality Improve Micro-Firm Performance? Evidence from the Brazilian SIMPLES Program", Journal of Development Economics, Vol. 94, pp. 262-276.

Farooq, A.; Kugler, A.; and Muratori, U. 2020, "Do Unemployment Insurance Benefits Improve Match Quality? Evidence from Recent U.S. Recessions", NBER Working Paper No. 27574.

Fedoretsa, Alexandra and Shupe, Cortnie. 2021. "Great Expectations: Reservation Wages and Minimum Wage reform," Journal of Economic Behavior \& Organization 183, March 2021, pp. 397-419.e

Furceri Davide, Jalles, João Tovar, and Prakash Loungani. 2019. "On the Determinants of the Okun's Law: New Evidence from Time-Varying Estimates," Comparative Economic Studies, 1-40. https://link.springer.com/article/10.1057/s41294-019-00111-1

Fields, G.S. 2005. A guide to multisector labor market models, Social Protection Discussion Paper 0505 (Washington, DC, World Bank).

Gasparini, L.; Tornarolli, L. 2007. "Labor informality in Latin America and the Caribbean: Patterns and trends from household survey microdata", CEDLAS Working Paper.

Genz, G.; Bellmann, L.; and Matthes, B. 2019. "Do German Works Councils Counter or Foster the Implementation of Digital Technologies? First Evidence from the IAB-Establishment Panel," Jahrbücher für Nationalökonomie und Statistik, Vol. 239, Nr. 3, pp. 523-564. 
Gimpelson, V.; Kapeliushnikov, R.; and Lukiyanova, A. 2010. "Employment Protection Legislation in Russia: Regional Enforcement and Labour Market Outcomes," Comparative Economic Studies, Vol. 52, Nr. 4, pp. 611-636.

Glover, Dylan; Pallais, Amanda; and Pariente, William. 2017. "Discrimination as a SelfFulfilling Prophecy: Evidence from French Grocery Stores," The Quarterly Journal of Economics, Volume 132, Issue 3, August 2017, Pages 1219-1260. Available at: https://doi.org/10.1093/qje/qjx006

Goldin, Claudia and Rouse, Cecilia. 2000. "Orchestrating Impartiality: The Impact of "Blind" Auditions on Female Musicians." American Economic Review, 90 (4):715-741.

Gollin, Douglas. 2002. "Getting Income Shares Right," Journal of Political Economy 110 (2): 458-74.

Gouin-Bonenfant, Emilien. 2021. "Productivity Dispersion, Between-Firm Competition, and the Labor Share," Unpublished Manuscript. Available at: https://drive.google.com/file/d/11Nyuz2P1HXJKvfkM4FUMZxss4Tav13Ai/view

Gutiérrez, Germán and Philippon, Thomas. 2017. "Declining Competition and Investment in the US," NBER Working Paper No. 23583.

Groves, Martha. 2019. "How California's 'Woman Quota' is Already Changing Corporate Boards," calmatters.org. Available at: https://calmatters.org/economy/2019/12/californiawoman-quota-corporate-board-gender-diversity/.

Haucap, J.; Pauly, U.; and Wey, C. 2001. "Collective Wage Setting When Wages Are Generally Binding: An Antitrust Perspective", International Review of Law and Economics, Vol. 21, Nr. 3, pp. 287-307.

Hayter, S. and Visser, J. 2018. "Collective Agreements: Extending Labour Protection,” (Geneva, ILO).

Heathcote, Jonathan; Kjetil Storesletten, and Giovanni L. Violante. 2007. "Insurance and Opportunities: A Welfare Analysis of Labor Market Risk,” NBER WP No. 13673.

Heckman, James J.; Lochner, Lance J.; and Todd, Petra E. 2006. "Earnings Functions, Rates, of Return and Treatment Effects: The Mincer Equation and Beyond," Chapter 7 in Handbook of the Economics of Education, Volume 1, edited by Eric A. Hanushek and Finis Welch, Elsevier B.V.

Heimberger, P. 2020. "Does Employment Protection Affect Unemployment? A Meta-analysis", Oxford Economic Paper, 1-26.

Heintz,J. and Pollin, R. 2005. "Informalization, economic growth, and the challenge of creating viable labor standards in developing countries", in "Rethinking Informalization: Poverty, Precarious Jobs and Social Protection”, N. Kudva and L. Beneria (eds.) Cornell University Open Access Repository.

Herr, H. and Kazandziska, M. 2011. Principles of Minimum Wage Policy - Economics, Institutions and Recommendations. (Geneva, ILO). 
Hijzen, A. and Martin, S. 2013. "The Role of Short-Time Work Schemes during the Global Financial Crisis and Early Recovery: A Cross-Country Analysis”, IZA Discussion Papers 7291, Institute of Labor Economics (IZA).

Hirsch, B.; Schank, T.; and Schnabel, C. 2010. "Works Councils and Separations: Voice, Monopoly, and Insurance Effects”, in Industrial Relations, Vol. 49, Nr. 4, pages 566-592.

Hsieh, C-T. and Olken, B. A. 2014. "The Missing 'Missing Middle' "Journal of Economic Perspectives, American Economic Association, Vol. 28(3), pages 89-108.

Hsieh, Chang-Tai, Eric Hurst, Chales Jones and Peter Klenow. 2019. "The Allocation of Talent and U.S. Economic Growth," Econometrica 87:5, 1439-1474. Available at: https://onlinelibrary.wiley.com/doi/abs/10.3982/ECTA11427

Hübler, O. and Jirjahn, U. 2003. "Works Councils and Collective Bargaining in Germany: The Impact on Productivity and Wages," Scottish Journal of Political Economy, Scottish Economic Society, vol. 50, nr. 4, pp. 471-491.

Hussmanns, R. 2004. "Measuring the Informal Economy: From Employment in the Informal Sector to Informal Employment," Working paper No. 53, Policy Integration Department, Bureau of Statistics (Geneva, ILO).

International Labour Organization (ILO), 1993, "Resolution concerning the International Classification of Status in Employment (ICSE-93)," January 1993. Available at: https://www.ilo.org/global/statistics-and-databases/standards-and-guidelines/resolutionsadopted-by-international-conferences-of-labour-statisticians/WCMS 087562/lang-en/index.htm

ILO. 2015. "Minimum Wage Policy Guide,” (Geneva: ILO). Available at: https://www.ilo.org/global/topics/wages/minimum-wages/lang--en/index.htm

ILO. 2017. “World Social Protection Report 2017-19,” November 2017 (Geneva: ILO). Available at: https:/www.ilo.org/global/publications/books/WCMS_604882/lang-en/index.htm

ILO. 2018a. "Women and Men in the Informal Economy: A Statistical Picture," Third Edition, April 2018 (Geneva: ILO). Available at:

https://www.ilo.org/global/publications/books/WCMS 626831/lang--en/index.htm

ILO. 2018b. "Global Wage Report 2018/19: What Lies Behind the Gender Pay Gaps,"

November 2018, (Geneva: ILO). Available at: https://www.ilo.org/global/about-theilo/mission-and-objectives/features/WCMS 650551/lang--en/index.htm

ILO. 2019a. "Organizing Informal Economy Workers into Trade Unions - A Trade Union Guide". June 19, 2019. Available at:

https://www.ilo.org/actrav/info/pubs/WCMS_711040/lang--en/index.htm

ILO. 2019b. "What Works. Promoting Pathways to Decent Work", October 17, 2019 (Geneva:

ILO). Available at: https://www.ilo.org/global/publications/books/WCMS_724097/lang-en/index.htm

ILO. 2000a. "Unemployment and Income Security" Discussion Paper prepared by Guy Standing for Geneva 2000: Follow-up to the World Summit on Social Development, Programme on Socio-Economic Security Papers No. 3 (Geneva: ILO, June 2000). 
ILO. 2020b. "Extending Social Security and Facilitating Transition from the Informal to the Formal Economy: Lessons from International Experience". June 29, 2020. Available at: https://www.ilo.org/secsoc/information-resources/publications-andtools/Brochures/WCMS 749431/lang--en/index.htm

International Monetary Fund (IMF). 2017. "Understanding the Downward Trends in Labor Income Shares", Chapter 3, World Economic Outlook, April 2017 (Washington DC, IMF). Available at: https:/www.imf.org/en/Publications/WEO/Issues/2017/04/04/worldeconomic-outlook-april-2017

IMF. 2021. "Recession and Recoveries in Labor Markets: Patterns, Policies, and Responding to the COVID-19 Shock," Chapter 3, World Economic Outlook, April 2021 (Washington $\mathrm{DC}, \mathrm{IMF})$.

Jacobson, Louis S.; Robert J. LaLonde; and Daniel G. Sullivan. 1993. "Earnings Losses of Displaced Workers," The American Economic Review, 83, no. 4, P. 685-709. Available at: http://www.jstor.org/stable/2117574

Jaumotte, F. and Buitron, C. 2015. "Inequality and Labor Market Institutions", IMF Staff Discussion Note No. 15/14. July 1, 2015. (Washington DC: IMF). Available at: https://www.imf.org/en/Publications/Staff-DiscussionNotes/Issues/2016/12/31/Inequality-and-Labor-Market-Institutions-42987

Johnston, A. C. 2021. "Unemployment Insurance Taxes and Labor Demand: Quasi-Experimental Evidence from Administrative Data", American Economic Review: Economic Policy, Vol. 13, No. 1, pp. 266-293.

Jütting, J.; Parlevliet, J.; and Xenogiani, T. 2008. "Informal Employment Re-loaded”, in IDS Bulletin, Vol. 39, No. 2, pp. 28-36.

Koh, Dongya; Santaeulàlia-Llopis, Raül; and Zheng, Yu. 2020. "Labor Share Decline and Intellectual Property Products Capital,” Econometrica, Vol. 88, Issue 6, pp. 2609-2628 November 2020. Available at: https://doi.org/10.3982/ECTA17477

Kugler, A.; Kugler M.; and Herrera-Prada, L. O. 2017. "Do Payroll Tax Breaks Stimulate Formality? Evidence from Colombia's Reform", Economía Journal, The Latin American and Caribbean Economic Association - LACEA, vol. 0 (Fall 2017), pp. 3-40, November.

Kuzmina, Olga and Melentyeva, Valentina. 2020. "Gender Diversity in Corporate Boards: Evidence from Quota-Implied Discontinuities," CEPR Discussion Paper No. DP14942.

Langot, F.; Merola, R.; and Oh, S. 2019. “Can Taxes Help Ensure a Fair Globalization?”, Policy Research Working Paper Series 8975, The World Bank.

Layard, R.; Nickell, S.; and Jackman R. 1991. Unemployment, Macroeconomic Performance and the Labour Market (Oxford, Oxford University Press).

Loayza, N. V.; Oviedo, A. M. ; and Servén, L. 2006. "The Impact of Regulation on Growth and Informality: Cross-Country Evidence." In Unlocking Human Potential: Linking the Informal and Formal Sectors. EDGI-WIDER.

Loayza, N. V. 2007. "The causes and consequences of informality in Peru," Working Papers 2007-018, Banco Central de Reserva del Perú. 
Loayza, N. V. 2018. "Informality: Why Is It So Widespread and How Can It Be Reduced?" World Bank Research and Policy Briefs No. 133110 (Washington, DC.)

Lucas, R. 1987. "Models of Business Cycles,” Oxford: Basil Blackwell

Manning, A. 2021. "Monopsony in Labor Markets: A Review”, in ILR Review, Vol. 74, Nr. 1, pages 3-26.

Manyika, James, Jan Mischke, Jacques Bughin, Jonathan Woetzel, Mekala Krishnan, and Samuel Cudre. 2019. "A New Look at the Declining Labor Share of Income in the United States,” Discussion Paper, McKinsey Global Institute.

Martinez, Joseba. 2018."Automation, Growth and Factor Shares," 2018 Meeting Papers 736, Society for Economic Dynamics. Meeting Paper 736, 2018.

Maurizio, R. and Vásquez, G. 2019. "Formal Salaried Employment Generation and Transition to Formality in Developing Countries: The case of Latin America," ILO EMPLOYMENT Working Paper No. 251 (Geneva).

Messina, J. and Vallanti, G. 2007. "Job Flow Dynamics and Firing Restrictions: Evidence from Europe”, The Economic Journal, Volume 117, Issue 521, pp. F279-F301.

Mincer, Jacob. 1974. "The Human Capital Earnings Function," Chapter 5 in Schooling, Experience, and Earnings, ed. Jacob Mincer, NBER, pp. 83-96.

Montenegro, Claudio and Patrinos, Harry. 2014. "Comparable Estimates of Returns to Schooling around the World," World Bank, Washington D.C. Available at: https://elibrary.worldbank.org/doi/abs/10.1596/1813-9450-7020

Mortensen, Dale. 2003. "Wage Dispersion: Why Are Similar Workers Paid Differently?," Cambridge: MIT Press.

Mortensen, Dale and Pissarides, Christopher. 1994. "Job Creation and Job Destruction in the Theory of Unemployment, Review of Economic Studies, 61, 397-415.

Mueller, S. and Stegmaier, J. 2017. "The Dynamic Effects of Works Councils on Labour Productivity: First Evidence from Panel Data," British Journal of Industrial Relations, Vol. 55, Nr. 2, pp. 372-395.

Nekoei, A. and Weber, A. 2017. "Does Extending Unemployment Benefits Improve Job Quality?", American Economic Review, Vol. 107, pp. 527-61.

Neumark, D. and Wascher, W. L. 2008. Minimum wages (Cambridge, MA., MIT Press).

Neumark, D. and Shirley, P. 2021. "Myth or measurement: What does the new minimum wage research say about minimum wages and job loss in the United States?," NBER Working Paper, No. 28388.

Organization for Economic Cooperation and Development (OECD). 2011. "Divided We Stand: Why Inequality Keeps Rising," OECD Publishing, Paris. Available at: https://doi.org/10.1787/9789264119536-en.

OECD. 2013. "The 2012 Labour Market Reform in Spain: A Preliminary Assessment," December 2013, OECD: Paris. Available at: https://www.oecd.org/employment/spainlabourmarketreform.htm 
OECD. 2015. "The Labour Share in G20 Economies," Available at::

https://www.oecd.org/g20/topics/employment-and-social-policy/The-Labour-Share-inG20-Economies.pdf

OECD. 2017. "OECD Employment Outlook: Collective Bargaining in a Changing World of Work", Chapter 4, OECD Publishing, Paris. Available at: https://www.oecdilibrary.org/employment/oecd-employment-outlook-2017/collective-bargaining-in-achanging-world-of-work empl outlook-2017-8-en

OECD. 2018. "Market concentration,” Issues paper, Paris, 2018. Available at: https://www.oecd.org/daf/competition/market-concentration.htm

OECD. 2020. "Job Retention Schemes During the COVID-19 Lockdown and Beyond", OECD Policy Responses to Coronavirus (Paris). Available at:

https://www.oecd.org/coronavirus/policy-responses/job-retention-schemes-during-thecovid-19-lockdown-and-beyond-0853bald/

Oesingmann, K. 2016. Extension of Collective Agreements in Europe, in CESifo DICE Report, Vol. 14, Nr. 2, pp. 59-64 (Munich, ifo Institute).

Okun, Arthur. 1962. "Potential GNP: Its Measurement and Significance," American Statistical Association, Proceedings of the Business and Economics Statistics Section.

Ostry, Jonathan; Alvarez, Jorge; Espinoza, Raphael; and Papageorgio, Chris. 2018. "Economic Gains from Gender Inclusion: New Mechanisms, New Evidence," IMF Staff Discussion Note/18/06 October. https://www.imf.org/en/Publications/Staff-DiscussionNotes/Issues/2018/10/09/Economic-Gains-From-Gender-Inclusion-New-MechanismsNew-Evidence-45543

Page, Scott E. 2017. "The Diversity Bonus: How Great Teams Pay Off in the Knowledge Economy," Princeton University Press.

Pagés, C. 2017. "Do payroll tax cuts boost formal jobs in developing countries?", IZA World of Labor, Institute of Labor Economics (IZA), pages 345-345, March 2017.

Perry, G.; Arias, O.; Fajnzylber, P.; Maloney, W.; Mason, A.; and Saavedra, J. 2007. "Informality: Exit and Exclusion". Washington, DC: World Bank.

Pignatti, C. 2016. "Do Public Employment Services Improve Employment Outcomes? Evidence from Colombia", ILO Working Papers 994904833402676, (Geneva: ILO).

Pissarides, C. 2000. Equilibrium unemployment theory. (Cambridge, MA., MIT Press).

Ratner, D. 2013. Unemployment insurance experience rating and labor market dynamics, Finance and Economics Discussion Series (Washington, DC., Federal Reserve Board).

Rogers, J. and Streeck, W. 1995. Works Councils: Consultation, Representation, and Cooperation in Industrial Relations. (Chicago, University of Chicago Press).

Rogerson, Richard and Schindler, Martin. 2002. "The welfare costs of worker displacement," Journal of Monetary Economics, 49 (2002) 1213-1234. Available at: https://www.sciencedirect.com/science/article/abs/pii/S0304393202001484 
Rothstein, J. and Zipperer, B. 2020. "The EITC and Minimum Wage Work Together to Reduce Poverty and Raise Incomes,” EPI Report (Washington, DC., Economic Policy Institute). Available at: https://www.epi.org/publication/eitc-and-minimum-wage-work-together/

Schmieder, J. F. and Von Wachter, T. 2016. "The Effects of Unemployment Insurance Benefits: New Evidence and Interpretation", Annual Review of Economics, Annual Reviews, vol. 8(1), pages 547-581, October.

Schnabel, C. 2013. "Union Membership and Density: Some (not so) Stylized Facts and Challenges," European Journal of Industrial Relations, Vol. 19, Nr. 3, pp. 255-272.

Schneider, F. 2004. "The Size of the Shadow Economies of 145 Countries all over the World: First Results over the Period 1999 to 2003," IZA DP No. 1431.

Scruggs, L. 2002. "The Ghent System and Union Membership in Europe, 1970-1996," Political Research Quarterly, Vol. 55, No. 2, pp. 275-297.

Shehu, E. and Nilsson, B. 2014. "Informal Employment Among Youth: Evidence from 20 School-to-Work Transition Surveys, (Geneva, ILO). Available at: https://www.ilo.org/employment/areas/youth-employment/work-foryouth/publications/thematic-reports/WCMS 234911/lang--en/index.htm

Shin, Y-K. and Böckerman, P. 2019. "Precarious Workers' Choices About Unemployment Insurance Membership After the Ghent System Reform: The Finnish Experience," Social Policy Administration, Vol. 53, pp. 921-938.

Slonimczyk, F. 2012. "The Effect of Taxation on Informal Employment: Evidence from the Russian Flat Tax Reform", in "Informal Employment in Emerging and Transition Economies", Vol. 34 of Research in Labor Economics, chapter 2, pp. 55-99, Lehmann, H. and Tatsiramos, K. (eds.).

Tatsiramos K. 2009. "Unemployment Insurance in Europe: Unemployment Duration and Subsequent Employment Stability", Journal of the European Economic Association, Vol. 7(6), pp. 1225-1260.

Torgler, B. and Schneider, F. 2007. "Shadow Economy, Tax Morale, Governance and Institutional Quality: A Panel Analysis,” IZA DP No. 2563.

Van Elk; K.; de Kok, J.; Durán, J.; and Lindeboom, G. 2014. "Enterprise formalization: Fact or fiction? A quest for case studies", ILO Geneva.

Van Ours J. C,and Vodopivec M. 2008.’Does Reducing Unemployment Insurance Generosity Reduce Job Match Quality?", Journal of Public Economics, Vol. 92(3-4), pp. 684-695.

Villanueva, E. 2015. "Employment and Wage Effects of Extending Collective Bargaining Agreements: Extending Provisions of Collective Contracts to All Workers in an Industry or Region May Lead to Employment Losses", in IZA World of Labor, Nr. 136 (Bonn, Institute for the Study of Labor).

Visser, J. 2013. ICTWSS: Database on Institutional Characteristics of Trade Unions, Wage Setting, State Intervention and Social Pacts in 34 countries between 1960 and 2007 Version 4. Available at: http://www.uva-aias.net/208. 
Waseem, M. 2018. "Taxes, Informality and Income Shifting: Evidence from a Recent Pakistani Tax Reform”, Journal of Public Economics, Vol. 157(C), pp. 41-77.

World Bank. 2008. "Del PANES al Plan de Equidad (Nota Técnica)”. Available at http://siteresources.worldbank.org/ INTURUGUAYINSPANISH/Resources/Notatecnica.pdf.

World Bank. 2019. "Global Economic Prospects, January 2019: Darkening Skies," Chapter 3 Growing in the Shadows: Challenges of Informality," January 8, 2019. Washington, DC: World Bank. Available at: https://openknowledge.worldbank.org/handle/10986/31066 